\title{
Kent Kimliği Göstergeleri Üzerinden Kentlilik Bilincine Dair Bir Okuma: Yalova Kenti Örneklemi
}

\author{
DOI: $10.26466 /$ opus.770453
}

*

\author{
Sibel Akova * \\ *Dr. Öğr. Üyesi, Yalova Üniversitesi, Sanat ve Tasarım Fakültesi, Yalova / Türkiye. \\ E-Posta: sibelakova@gmail.com \\ ORCID: 0000-0001-7680-7394
}

\begin{abstract}
Öz
Tarihi, ruhu, mimari yapısı, kültürel unsurları, jeopolitik konumu, tabiat varlıkları ve sosyal oluşumları ile bir kente doku ve anlam kazandıran öğeler, dünya cŏ̆rafyasında varlı gösteren her bir kente dair farklı anlamlarm yüklenmesine sebebiyet vermektedir. Birbirlerinden farklı öğeleri uhdelerinde barındıran kentler, sahip olduklar özellikler ile diğerlerinden farklılaşmaktadırlar. İlgili farklllıklar, kentlerin sosyal dokuların da oluşturmakta, birey ve toplumlar üzerinde aidiyet hissiyatın oluşturmaktadır. Tarihi dokuları ile farklı medeniyetlerin kültürel öğelerini, estetik ve kültürel unsurların, mimari yapıların, inanç faktörlerini ve sosyal yaşam pratiklerini günümüze değin aktaran kentler, zaman ve mekan mihverinde medeniyetlerin nakşetmiş oldukları kıymetleri günümüze değin taşımaktadırlar. Nakşetmişs oldukları kıymetleri günümüze değin taşıma kabiliyetini haiz olan şehirler, bu yönü ile yaşayan bir organizma olarak addedilmektedirler. Bu sebeple, maddi kültür bağlamında gerçekleştirilen mekan ve yapı odakl okumalar ile birlikte kentlerin, manevi kültürünü yansıtan pek çoköğenin de tahlil edilmesi gerekmektedir. Zira kentlerin uhdesinde barman birçok unsur, birey ve toplumlar üzerinde güçlü tesirler yaratmaktadır. Kentlerin de bireylere benzer şekilde kendilerine özgü kimlikleri oluşmaktadır. Kentlerin kimliklerine özgü karakterleri, kendilerini diğer kentlerden ayırmaktadır. Kent yapılarının giderek gelişme gösterdiği günümüzde, kentlilik bilincinin yapı taşı niteliğini haiz olan kentlilik ve kentlileşme kavramlarının sorgulanması, kentlerin sağllklı ve sürdürülebilir gelişimlerinde büyük önem arz etmektedir. Çalışmanın temel konusunu oluşturan kentlilik bilinci ve unsurlarmm kent kimliği göstergeleri üzerinden sorgulamasl, Yalova kenti örneklemi bağlamında gerçekleştirilmektedir. Kentlilik, kentlileşme ve kentlilik bilinci kavramlarının fenomenoloji yöntemi ile sorgulandığı çalışmada, Yalova kentlileri çalışmanın da örneklemini oluşturmaktadır.
\end{abstract}

Anahtar Kelimeler: Kentlilik, Kentlileşme, Kültürlenme, Kentlilik Bilinci. 


\title{
A Reading on Awareness of Urbanity Through City Identity Indicators: Yalova City Sample
}

\begin{abstract}
Elements that give a city texture and meaning with its history, soul, architecture, cultural elements, geopolitical position, nature's assets and social formations are all contributing to different meanings of each city that are present in the world geography. Cities, which have different elements from each other, differ from others with their features. Related differences also form the social fabric of cities, creating a sense of belonging over individuals and societies. The cities, which have conveyed the cultural elements, aesthetic and cultural features, architectural structures, belieffactors, and social life practices of different civilizations with their historical textures, carry the values that civilizations embroidered in time and space. Cities that have the ability to carry the values they have embroidered until today are considered as living organisms with this aspect. For this reason, space and structure-oriented readings carried out in the context of material culture and many elements reflecting the spiritual culture of cities should also be analyzed. Because many elements in the cities have strong effects on individuals and societies. Similar to individuals, cities have their own unique identities. The characters unique to the cities 'identities distinguish themselves from other cities. In today's world, where urban structures are increasingly developed, questioning the concepts of urbanity and urbanization, which are the building blocks of urban awareness, is of great importance in the healthy and sustainable development of cities. The main subject of the study is the questioning of urban awareness and its elements on the indicators of urban identity within the context of the Yalova city sample. In the study in which the concepts of urbanity, urbanization and awareness of urbanity are questioned by the method of phenomenology, Yalova citizens constitute the sample of the study.
\end{abstract}

Keywords: Urbanity, Urbanization, Culturation, Awareness Of Urbanity. 


\section{Giriş}

Sosyal bir varlık olan bireyin sosyalleşme süreçlerinden biri olarak addedilen kentlileşme ve kentlilik olguları, kentlilik bilinci kavramı üzerinden irdelenmeyi mümkün kılan, kentin sakinleri tarafindan sahiplenme ölçütünün birer göstergeleri olma özelliğini taşımaktadırlar. Yerleşik yaşama geçiş ile birlikte şekillenen kent yapılanmaları, zaman içerisinde her dönemin gerekliliklerine ve her kültürün şartlarına koşut olarak değişimlere uğrayarak addedilmiş ve farklı anlamlar yüklenmiştir. Kendi iç dinamikleri ile durağanlıktan uzak bir yapı sergileyen kentler, dönemin şartlarından, çevre ve mevsimsel etkilerden, doğa olaylarından, siyasi yapılanmalardan ve kültürlerin öğelerinden etkilenerek, birbirlerinden farklı işlevlere, farklı yapılara ve farklı görünümlere bürünerek günümüze değin erişmişlerdir. Teknolojik gelişmeler, hızlı sanayileşme, iletişim ve ulaşım altyapılarındaki mevcut ilerlemeler, küreselleşme sürecinin etkileri, eğitim oranının yükselmesi ve olanaklarının yaygınlaşması, kırsal (köy) yerleşimlerden kentlere uzanan göçler, kent yapılarına ve kentlilerin yaşamlarına tesir eden süreçler olarak addedilmektedir. Yaşayan ve sürekli gelişim ile değişimlere açık olan kentler, uhdesinde barındırdıkları bireylerin kenti sahiplenmelerine ve kentin sunduğu imkanlardan faydalanma oranlarına koşut olarak mekan haline dönüşmektedirler.

Bireylerin ulaşım kolaylığı yaşadıkları, kamusal ve özel alanları ile yapılaşmış veya doğal şekli ile kentin imkanlarından faydalandıkları, artan beklentilerinin karşılandığı, çevresel mekanların ihtiyaçlara göre ve yaşam kalitesinin artırılmasına yönelik şekillendirildiği kent yerleşimlerinin tercih edilebilirliği, yoğunluğu, gelişimleri ve aidiyetleri de farklı düzeylerde gerçekleşecektir. Kültürlerin şekillendiği, uygarlıkların varlık gösterdiği, toplumların büyüyüp geliştiği mekanlar olan kentler, birey ve toplumların gelişimlerini etkileyen en önemli faktörlerden biri olarak addedilmektedirler. Günümüzde kentler yaşam alanları olmalarının ötesinde, yaşayan birer varlık olarak kabul görerek, duygusal bağın geliştirildiği, koruma içgüdüsünün ve aidiyet ile sorumluluk hissiyatının ortaya çıtı̆̆ı, anlamlar yüklendiği bir bilincin oluştuğu birer olgu haline gelmişlerdir. Birey ve toplumların hafızalarında yer edinen kent olgusu, dinamik yapısı ile yine birey ve toplumların yaşamlarının değişimlerinde öncü rol üstlenmektedir. Bireylerin bir arada yaşama gereksinimleri sonucu elde ettikleri 
deneyimler, birlikte (ortak) yaşam pratiklerini de beraberinde getirmektedir. İş bölümünün, uzmanlaşmanın, kültürlenme süreçlerinin ve örgütleşmenin üst seviyelerde yaşandığı, tarım dışı üretim faktörlerinin ağırlıklı olduğu kent yerleşimleri, farklı kimliklerin, farklı kültürlerin ve farklı etnik kökenlerin bir araya geldiği, heterojen yapıları ve kendilerine özgü özellikleri ile ön plana çıkmaktadırlar.

Birlikte yaşam pratiklerinin varlığı, kentlerin kendilerine özgü birer kimlik kazanmaları sonucunu da beraberinde getirmiştir. Elbette kimlik kazanımları meselesinde kentte ikamet eden bireylerin, toplumların ve yönetim erklerinin rolü büyüktür. Zira, ekonomik, tarihi, mimari, kültürel ve mekânsal bileşenleri ile kentler, bir yandan kendi gelişimlerine öte yandan da toplumsal dönüşümlere ve dahi bireyler arası iletişim biçimlerine ve ilişki düzeylerine önemli katkılar sunmaktadırlar. Bu yönü ile yaşayan mekanlar olan kentler, korunmaya, planlı yapılaşmalara, bilinç oluşturulmaya, benimsenmeye ve dönemin şartlara uygun şekilde yenilenmeye ihtiyaç duymaktadırlar. Bu sebeple bireyler açısından da kentler salt yaşam alanları olmaktan çıkmış, farklı boyutlarda anlamlar yüklenen birer kimlik ile özdeşleştirilmişlerdir. Günümüzün kimlik kazanan kent yapıları, birey ve toplumlar ile bağ kurma özelliğini kazanmışlardır. Birey ve toplumlar zamanla yaşadıkları kentin kimlik yapıları ile bağlarını güçlendirerek, kente dair bilinç kazanmışlardır. Kentlilik bilinci olarak literatürde yer edinen olgu, bireylerin zamanla kent yaşamları sürecinde kentlileşerek, kente dair aidiyet hissiyatı oluşturmalarına, kentle bir bağ kurmalarına ve kendilerini kentin içerisinde konumlandırmalarına bağlı olan bir süreçtir. Birey ve toplumların, sosyal, kültürel, ekonomik, siyasi ve sivil alanlarda gerçekleştirdikleri faaliyetler, kentlilik bilinci olgusunun da birer göstergesi olma özelliğini taşımaktadır. Katılım ve gönüllülük esası temelli gerçekleştirilen faaliyetler, kent, kentleşme, kentlileşme ve kentlilik bilinci kavramlarının yapısını şekillendirdiği gibi kentlerin geleceği adına da büyük önem arz etmektedir.

\section{Kent ve Kentleşme Olgularının Kavramsal Çerçevesi}

Kent ve kentleşme kavramları, pek çok farklı disiplin ve birçok özgün araştırmada farklı değişkenler temel alınarak izah edilmeye çalışılan, bir- 
birinden bağımsız pek çok değişkeni uhdesinde barındıran, karmaşık yapıların değişimleri ile şekillenen ve çerçeveleri dönemin şartlarına koşut olarak farklılaşan olgulardır. En üst seviyede addedilen "iktisadi iş bölümünün merkezi olan" (Simmel, 2011:98) kentler, birçok kültürün ve kimliğin varlık gösterdiği, sürekli değişen ve karmaşık hale dönüşen ilişkileri uhdesinde barındıran yaşam alanları olarak kavramsallaştırılmaktadır. Yerel kimlik ve kültür unsurlarını bir arada tutan, farklı kimlik ve kültür öğelerini bütünleştirerek, bir potada eritilmesi suretiyle harmanlayan yerleşim birimleri olan kentler, yönetimsel, sosyal, kültürel ve siyasal vurgulara karşılık gelen, tarihsel süreç içerisinde anlamı çeşitlenen, dinamik özellikleri ile ön plana çıkan yaşayan organizmalardır. "Kentte olmaya özgü hayatın yaşandığı, kamusal alanlar aracılığıyla paylaşıldığı ve yeniden üretildiği yerler" (Kotler, 1993, s.2), olarak tanımlanan kentler, "sürekli bir akış içerisinde bulunan bir toplumsal pratiği ifade etmektedirler" (Castells, 1997, s.123). Bu yönü ile her dönem ve her nesil değişimlere uğrayan, üretim, sanat, kültür, doğa ve ticaret ağırlıklı yapıları ile ön plana çıkan kentler, "sürekli bir değişim ve devinim içindedir. Bu açıdan bakıldığında ise kentlerin, canlı bir varlık" (Weber, 1966, s.10) olduğunu ifade etmek mümkündür.

Uygarlık kavramı ile ilişkilendirilen kent kavramı, farklı dillerde benzer manalarda, farklı kültürlerde emsal anlamlarda karşılıklara denk gelmektedir. Castells'e göre kent, "esas olarak bütün toplumsal grupların konut, eğitim, sağlık, kültür, ticaret, ulaşım gibi günlük yaşamının temelinde yer alan ortak tüketim araçlarının örgütlenmesiyle ilişkilidir" (1997, s.14). Kavramsal çerçevesi çizilmiş bir kent kavramına yoğunlaşmanın güç olduğunu ifade etmek mümkündür. Zira Harvey'in ifadesi ile kent, "kuşkusuz karmaşık bir şeydir" (2006, s.27). Bu sebeple, toplumsal öğeleri uhdesinde barındıran kent (şehir) kavramı, temelde bir yerleşim yeri olmak ile birlikte, bütüncül bir bakış açısı ile değerlendirildiğinde "uygarlık" (medeniyet) kavramı ile özdeşleşmektedir. Etimolojik manada incelendiğinde kent kavramı Latin dillerinde cite kavramına karşılık gelerek, İngilizce dilinde city, Fransız dilinde cité kelimeleri ile anlamlandırılmıştır. Sosyal, siyasal, ekonomik, kültürel, bilimsel ve toplumsal ilişkilerin yürütüldüğü yaşam alanları olan şehirler, toplumsal yaşamın değişimlerine ve döneminin gelişimlerine kaynaklık eden, sanayileşme, uzmanlaşma, ör- 
gütlenme ve iş bölümünün en yoğun şekilde yaşandığı 1 ve ikincil ilişkilerin ön plana çıktığı bölgelerdir. Kent aynı zamanda, "Bir evler topluluğuna sahip olmasının yanı sıra, kendisine ait toprağa dayalı mülkiyeti, gelir ve giderlerden oluşan bir bütçesiyle aynı zamanda iktisadi birliğe sahip bir birimdir" (Weber, 2003, s.95).

Söz konusu yaşam alanları aynı zamanda, medeniyetlerin ve kültürlerin de ortaya çıtı̆̆ı 1 ve gelişme imkanı buldukları mekanlar olarak addedilmektedirler. İnsanlık tarihi ile özdeş bir yapıya sahip olan kentler, yerleşik yaşama geçiş ile birlikte bireylerin ve toplumların yaşamlarında önemli bir yer edinmişlerdir. Tarihi geçmişleri insanlık tarihine koşut olan kent kavramı, her dönemde farklı özellikleri ile insanoğlunun yaşamında farklı ihtiyaçların karşılandığı alanlar olarak tanımlanmaktadır. Yerleşik yaşama geçiş ile birlikte ekolojik bağlamda yaşam ihtiyaçlarına imkan veren kentlerin tercih edilebilirliği zamanla sanayileşmenin ve teknolojinin yön verdiği kentler ile ikame edilmiştir. İnsanlık tarihinin kayıt altına aldığı her dönemin deneyimleri, birey ve toplumların ihtiyaçlarını da farklılaştırmaktadır. Farklılaşan ihtiyaçlara karşılık gelen öğeleri uhdesinde barındıran kentler, muadillerine oranla daha yüksek düzeyde tercih edilebilir konuma erişmişlerdir. Birey ve toplumların yaşamlarına imkan veren bereketli nehir yataklarına ve verimli alanlara sahip kentlerden, teknolojinin ve sanayinin yoğunluk kazandığ kentlere değin birey ve toplumların değişen ihtiyaçlarına göre önem derecesi farklılaşan kentler, tarihsel süreç içerisinde pek çok kültür ve medeniyetin gelişmesine eşlik etmişlerdir. Temel ihtiyaçların giderilmesi, tabi yaşamın olumsuzluklarının bertaraf edilmesi, birlikte yaşam pratiklerinin etüt edilmesi ve hayatta kalma mücadelesinin sonucu ve çözümü olarak ortaya çıan kent yapılaşmaları, tarihsel süreç içerisinde mekânsal bileşenleri, sosyal, ekonomik, kültürel, savunma ve üretim unsurları ile karmaşık bir yapıya bürünmüşlerdir.

İlgili bütünleşik yapı, kentlere özgün kimlikler yüklemekte, toplumsal yapıya ve sosyal yaşama farklılıklar sağlamakta ve birey ile toplumlar arasındaki iletişim biçimlerine de yön vermektedir. Savunma odaklı kurgulanan ve seçilen yerleşim birimleri, bilhassa, üretim sistemlerinin ve sanayinin gelişimi ile birlikte, heterojen bir toplum yapısını beraberinde getirerek, yönetim şekillerini de dönüşümlere uğratmıştır. Söz konusu hete- 
rojen yapı, bireyselliği, iş bölümünü, uzmanlaşmayı ve ekonomik hamleleri de ön plana çıkarmıştır. İlgili hamleleri başarı ile gerçekleştiren kentler, farklı anlamlar yüklenerek türevlerinden ayrılarak, gelişme göstermişlerdir. Şehir yaşamlarında ön plana çıkan ekonomik yapının gücü ile istikrarı, şehir yerleşimlerini kırsal alanlara kıyas ile daha cazip hale getirmektedir. "Kentin sunduğu fırsatların ve kentsel yaşamın çekiciliği kentleşmeyi hızlandıran etmenlerdir" (Stevenson, 2003, s.14). Kırsal alanda mevcut olan tarım faaliyetlerinin sınırlılığ larının yetersizliği, şehir yerleşiminin tercih edilebilirliğini de artırmıştır. Bu bağlamda, şehir yerleşimlerini kırsal alanlardan ayıran en önemli unsurların, ekonomik anlamda istikrarlı yapıları, sanayileşme ile beslenen güçlü iş bölümü ağları, tarım da dahil olmak üzere makineleşme sonucu ilkel yöntemlerin terk edilmesi, pek çok alanda yeni üretim tekniklerinin kullanımı sonucu yeni istihdam alanlarının ortaya çıkması, ulaşım ve alt yapı imkanlarının iyileştirilmesi ve teknolojik gelişmelerin varlığı olduğunu ifade etmek mümkündür.

Üretim bağlamında tarım ekonomisinden sanayi ve hizmet alanlarına geçişin, gelir anlamında çeşitliliğin, istihdam bağlamında farklılığın, uzmanlık anlamında yoğunluğun, kültürel bağlamda çokkültürlülüğün, sosyal manada örgütlülüğün, yönetim ve siyasal anlamda değişik bakış açılarının varlı̆̆ının ifadesi olan şehirleşme olgusunun, salt ekonomik bir olgu olduğunu ifade etmek sığ bir tanımlamayı da beraberinde getirecektir. Ekonomi ve nüfus artışı parametreleri bağlamında gerçekleştirilen kent tanımlamaları, kentin uhdesinde barındırdığı, rekabet unsurunu, mücadele dürtüsünü, sanat ile kültür birikimlerini, mekan algısını, entelektüel bakış açısını, konfor ihtiyacını, kendini gerçekleştirme hissiyatını ve türevlerini göz ardı etmek anlamına gelmektedir. "Kent sayısının ve kentte yaşayan nüfustaki niceliksel artışın" (Tannenbaum, Schultz, 2005, s.117), ifadesi olarak addedilen kentleşme olgusu, yeni, özgün ve karmaşık bir yaşam şeklinin de ifadesini oluşturmaktadır. Ekonomik coğrafya oluşlarının yanı sıra kültürel, siyasal ve sosyal alanlar olarak da anılan kentler, salt demografik değişimler (göçler) ile açıklanamayacak nitelikte, ulusal ve uluslararası ölçekte sosyo-ekonomik değişimlerden etkilenen ve dahi dönüşümlere yön veren çok katmanlı ve birbirinden bağımsız parametreler (ölçüt) içeren bir olgudur. 
Kentleşme ise siyasal, sosyal, ekonomik, çevresel, yönetsel, mekânsal ve kültürel bağlamda bir değişim sürecinin ifadesidir. En yaygın anlamı ile kentleşme, kentlerin ortaya çıkması ile birlikte, bilhassa Sanayi Devrimi ile birlikte sayılarının artması, göçler ile birlikte kent yerleşimlerinde ikamet eden birey ve toplum sayısının çoğalması ve ilgili artışlar bağlamında yaşanan değişim ile gelişimler olarak addedilmektedir. Lefebvre' ye göre "büyüme sanayileşme süreciyle, gelişme ise kentleşmeyle ilgilidir. Kentleşme, sanayileşmeye anlam verir" (2007, s.95). Ekonomik ve sosyal değişimlerin odağında anlamlandırılan kentleşme süreci aslında fiziki, siyasi, çevresel ve kültürel pek çok bileşeni de uhdesinde barındırmaktadır. İlgili bileşenler bir çarklının dişlerinin işleyişi biçiminde birbirlerini etkileyerek, birey ve toplumların yaşamlarında sosyal, kültürel, mental, psikolojik ve mekânsal nitelikte yapısal değişimleri de beraberinde getirmektedir. Bu yönü ile kentleşme sürecini salt demografik veriler ve coğrafi alanların çokluğu ile açıklamak doğru bir yaklaşımı yansıtmamaktadır. Zira kentleşme, ekonomik, kültürel, sosyal, teknolojik ve psikolojik nitelikli değişimlerin ifadesi olan dinamik bir süreç ile karşılık bulmaktadır. Birey ve toplumların yaşantılarında başat etkileri olan kentleşme süreci, birey ve toplumların kente özgü yaşam biçimlerini benimsemeleri ile anlam bulmaktadır.

\section{Kentlileşme ve Kentlilik Bilinci Süreçleri Üzerine Bir Değerlendirme}

Kentleşme sürecinin sosyal değişim ve bütünleşme boyutuna atıf yapılan kentlileşme, kente göç eden, kentte ikamet eden veya varlık gösteren birey ve toplumların değer sistemini, norm yapısını, davranış ve tutum kaidelerini, düşünce yöntemlerini ve kente dair oluşturulan kaideleri yaşam biçimi haline getirmelerini ifade eden bir yaşam biçiminin adıdır. Kentlileşme, birey ve toplumların geçmiş yaşam tecrübeleri ile varlık gösterdikleri kentlerde bulunma süreleri, güncel yaşam pratikleri, demografik yapıları (yaş, cinsiyet, medeni durum, meslek grubu, eğitim düzeyi) iletişim kurdukları sosyal çevre ve ilişki içerisinde bulundukları kurum deneyimleri ve etkileşim halinde oldukları toplumsal paydaşlar olmak üzere, örneklerinin çoğaltılması mümkün olan pek çok etken ve değişken ile ilintili bir süreçtir. İlgili süreç birey ve toplumların mevcut davranış kalıplarında, tutuma dair yapılarında, alışkanlıklarında, zevk, beğeni, tercih, istek ve 
karar verme süreçlerinde, sosyal, ekonomik, siyasal, psikolojik, kültürel, çevresel, estetik ve inanç bağlamında değişimlere sebebiyet vermektedir. $\mathrm{Bu}$ sebeple, genel anlamda ideal bir kentli birey prototipi oluşturulmak istense dahi, belirli bir zaman dilimi içerisinde, belirli bireyler arasında, belirli toplum kümeleri dahilinde varlık gösterilen kentin unsurlarına bağlı olarak farklı düzeylerde gelişen aidiyet hissinin getirdiği bir kentli birey prototipi oluşmakta ve ilgili kentli tipi de kentlileşme sürecini şekillendirmektedir.

Bu saik ile bir kentte yaşayan birey ve toplumların yaşamlarını idame ettirmek adına gerçekleştirdikleri faaliyetlerin kentlileşme olgusu olarak nitelendirilmesi doğru bir düşünce biçimini yansıtmayacaktır. Zira kentlileşme süreci salt olarak şehirlerin nicelik ve nitelik bağlamında gelişmesi ve şehir nüfusunun artması ile açılanamayacak kadar farklı parametreleri uhdesinde barındıran bir kavramdır. İlgili süreç, bireylerin kentlileşme edimini gerçekleştirdikleri kentlerin kültürüne dahil olmadan evvel yetiştikleri kültürün ve coğrafyanın tabiatının izleri çerçevesinde, her bir birey ve her bir toplum bağlamında farklı düzeylerde gerçeklemektedir. Geçmiş yaşam deneyimleri ile günlük yaşam pratiklerinin, varlık gösterilen kentin kültürü ile harmanlanması süreci olan kentlileşme olgusu, yaşam biçimlerinin değişimi durumunu da beraberinde getirmektedir. Kent ile bütünleşme, kentin sahip olduğu unsurları benimseme, kentin başat öğeleri ile duygusal bir bağ kurma, kente dair aidiyet hissiyatı edinme, kentin olağan ritmine uyum sağlama ve kent kültürüne koşut ilişkilerin geliştirilmesi edimlerini kapsayan kentlilik süreci, yaşam deneyimleri ve tecrübeleri ile belirli ritüellerin, temayüllerin, davranış kalıplarının ve düşünce yapılarının oluşması ve gelişmesi ile ilintili bir kente özgülük durumudur. Kentte ikame etme ile başlayan ve belirli zaman dilimlerini kapsayan, kente dair kültür ile özdeşleşme yoluyla sağlanan bir süreç olan kentlileşme, kent dışı yerleşim alanlarında gözlenen davranış, algı ve düşünce kalıplarından farklı özellikler taşıyan bir değişim sürecini beraberinde getirmektedir.

Kentlileşmenin temel zeminini oluşturan kente yerleşim, birey ve toplumların yaşam tarzlarında, düşünce sistemlerinde, kültürel öğelerinde, değer yargılarında, tutum ve davranış yapılarında ve yaşam koşullarında değişimlerin de öncü kuvvetini oluşturmaktadır. Bu sebeple kentlileşme sürecinin yaşanması adına başat unsurun değişim olduğunu ifade etmek 
mümkündür. Değişime açık olma ve değişim unsurunu kabul etme edimi, kentlileşme olgusunun ön koşulu niteliğini taşımaktadır. Kültürel, ekonomik, sosyal, psikolojik ve çevresel bağlamda birçok değişimin yaşanmasını mümkün kılan kentlileşme, düşünsel boyutu ile kentli ve kırsal bireylerin yaşam tarzları başta olmak üzere, niteliksel ve kavramsal farklılıkları ortaya çıkarmaktadır. Doğup büyülen veya göç edilen kentte ikamet eden birey ve toplumların kente özgü davranış kalıplarını benimseyerek, kente dair objeler ile bütünleşmelerini ifade eden kentlileşme, birey ve toplumları kentin bir öğesi olma durumuna taşıyan uzun soluklu bir yaşam pratiğidir. Kent yaşamı pratiği içerisinde toplum düzeyinde yaşanan kentleşme olgusu, birey düzeyinde kentlileşme süreci ile karşıllık bulmaktadır. Kentsel yaşamın birikimi mahiyeti niteliğinde addedilen kent kültürüne uyum ve kent yaşamını içselleştirme durumu, kentlileşme kavramı ile anlam bulmaktadır. Kent kültürüne uyum sağlamak ve kentin sunduğu sosyal, psikolojik, ekonomik, estetik ve kültürel varlıkları içselleştirme edimi kentlilik bilinci kavramının da göstergelerini oluşturmaktadır.

Varlık gösterilen kenti sahiplenme, kent sorunları ile alakadar olma, kente dair mevcut gelişmeleri takip etme, kentin dönüşümüne koşut farkındalık geliştirme, kentsel aidiyet hissiyatını tesis etme, kent kurumlarına ve kentsel çalışmalara katılım ve kente dair kültüre, sembollere ve anlamlara uyum unsurları kentlileşme sürecine dair birey ve toplumların başat kazanımları olarak addedilmektedir. İlgili kazanımlar, kentlileşme sorunlarından sosyal çatışmaya değin pek çok olumsuzluğun önüne geçebilme yetisi olan unsurlardır. Varlık gösterilen kentin manevi ve maddi varlıklarının benimsendiği ve kentlileşme sürecinin yaşam biçimi haline dönüştügü kentlilik bilinci (urban consciousness), psikolojik, sosyal, ekonomik, siyasal ve çevresel etmenleri ile yeniden bir sosyalleşme sürecinin ifadesidir. Birbirlerinin birer doğal sonucu olarak addedilen sırası ile kentleşme, kentlileşme ve kentlilik bilinci kavramları, birey ve toplumların kentsel yaşam pratikleri dahilinde edindikleri davranış değişiklikleri ile karşılaştıkları kültür etkileşimleri sebebi ile bir kültürlenme süreci olarak da addedilmektedir. Birbirlerinden farklı özelliklere sahip bireylerin, farklı kültürlerin, farklı kimliklerin, farklı inançların bir arada ve ortak yaşam pratiklerinin gelişmesine zemin hazırlayan kent olgusu, uzun süreleri kapsayan deneyim ve tecrübelerin ışığında kentlilik bilincinin kazanıminda temel rolü üstlenmektedir. 
İlgili rol farklı kimliklere, statülere, dillere, inançlara ve kültürlere mensup bireylerin farklılıklarının ötesinde varlık gösterdikleri kent ile özdeşleşen bir kimlik yapısını içselleştirmelerini mümkün kılmaktadır. Kentlilik bilincinin ilk adımı olan, bireylerin ve toplumların kendilerini varlık gösterdikleri kentin bir parçası olarak addedebilmeleridir. "Kentlilik bilinci, kent kültürünü anlamak, kendini kente, kentin dinamiklerine ait ve güvende hissetmek, kentsel oluşumlardan sorumluluk duymak olarak kavramsallaştırılabilir" (Bayındırlık ve İskân Bakanlığı, 2009, s.17). Elbette kentlilik bilincinin oluşabilmesi adına bireylerin salt olarak aynı kentte varlık göstermeleri durumu yeterli değildir. Aynı şekilde, homojen olmayan bir yapıya sahip olan kent yapılarında varlık gösteren her bir bireyin benzer ölçütlerde kentlilik bilincine sahip olmaları çıkarımı da gerçekçi değildir. Her bir bireyin kentlilik bilinci düzeyi ve kente dair geliştirdikleri aidiyet hissiyatı da doğaldır ki farklı düzeylerde gerçekleşecektir. Bireylerin varlık gösterdikleri kente kendilerini ait hissetmeleri ve kendilerini kentli olarak tanımlamaları, kentli kimliğini kazanmaları, kentin gelişimi hususunda siyasal, sosyal, ekonomik ve kültürel anlamda yapıcı nitelikte faaliyetlere katılımları, kent kültürünün korunması ile canlılığ1nın sürdürülebilirliği adına farkındalık kazanmaları, kenti sahiplenmeleri ve kendi geleceklerinin inşasına koşut olarak kentin geleceğine dair kayg1 gütmeleri, kentlilik bilincinin başat unsurlarını oluşturmaktadır.

Kentlilik bilinci kente dair var olan kıymetlerin somut göstergesi niteliğini haiz bir farkındalıktır. Kent birbirlerinden farklı insan tipolojilerini, farklı kültürleri, farklı lisanları, farklı sosyo-ekonomik yapıları, farklı tutum ve davranış biçimlerini, farklı manevi ve toplumsal değer yargılarını uhdesinde barındıran bir kültürlenme alanıdır. Bu sebeple, birbirlerinden farklı kültürlerin, düşünce dünyalarının ve toplumsal hafızaların karışımı olan kentlerde, her bir bireyin kentli olma hissiyatı, kültürlenme süreci ve kentlilik bilinci düzeyleri de birbirlerinden farklılık gösterecektir. Kentlileşmiş bireylerin varlığının ve düzeyinin kentlilik bilincine koşut olarak addedildiği günümüzde, kentin imkanlarından farklı düzeylerde yararlanan bireylerin kentlilik bilici de birbirlerinden farklı niteliklerde gerçekleşecektir. Eğitim düzeyi, demografik unsurlar, sosyo-ekonomik faktörler, kültür, etnik köken ve alt kültür, inanç yapıları bireylerin üzerinde kentlilik bilinci oluşumunda farklılıklar ortaya çıkarmaktadır. Kentlilik bilincinin oluşumunda aile yapısı başta olmak üzere, eğitim kurumları, sivil 
toplum örgütleri, hemşehrilik ile dayanışma dernekleri büyük önem arz etmektedir. Ancak ilgili yapıların varlığı kadar, yerel yönetimlerin de tutum ve faaliyetleri kentlilik bilincinin oluşumunda başat rol oynamaktadir.

Yaşanılabilir bir kent hayatının kabulü, şüphesiz ki kentlilik bilinci çerçevesinde toplanmaktadır. Farklı kimlikler ile ortak yaşam kültürünün bir sentezi olan kentlilik bilinci, aslında yeni bir kimliğin oluşturulması olarak da anlamlandırılmaktadır. Yeni bir kimliğin kazanılması adına kent yaşamında sosyalleşmeyi sağlayan, bütünleşme aşamalarını gerçekleştiren ve uyum sürecini koordine edebilen aracı kurumların varlığı elzemdir. İlgili aracı kurumların başında ise yerel yönetimler gelmektedir. Zira, yerel yönetimler bireyler üzerinde, aile, sosyal gruplar, eğitim kurumları, sivil toplum örgütleri ve hemşehrilik derneklerinin üzerinde bir güven ortamı sağlamaktadırlar. Bu sebeple yerel yönetimler, kentlilik bilinci aşılanması noktasında kültürel etkileşim sürecine aracılık ederek ve yeni bir kent kimliğinin kabulünü mümkün kılmakta ve bireylerin sosyalleşme süreçlerine de katkı sağlayabilmektedirler. "Tarihi, kültürel bilinçle ahlaki değer ve kent kimliğinin şekillenmesinin çarpıcı bir örneği olan" Yalova kentinin "zengin tarihi mirasının korunup gelecek nesillere aktarılması" (Çolak, Türkmen, Hanilçe, 2017:83), düşüncesinin elzem olduğu görüşünden hareketle, Yalova kentlilerinin kentlilik bilinci ve farkındalıklarının ölçümü teori bağlamında betimlenen çalışmanın uygulama sürecini oluşturacaktır.

\section{Kent Kimliği Göstergeleri Bağlamında Yalova Kent Kimliğini Okuma Araştırmasının Metodolojisi}

Kentlerin de bireyler gibi kendilerine özgü şahsiyetleri vardır. Ve bu özellikler kentleri birbirinden ayırır ve onlara şahsiyet/kimlik kazandırır. Yeni kentsel gelişmenin giderek standartlaştığı bir çağda bunlar, bir kentin öbür kentten farklı oluşumuyla hemen ayırt edilmektedir (Shaukland, 1996, s.24). Kent olgusu, kavramsal bağlamda çerçevesi çizilmemiş, müşterek bir tanım üzerinde mutabık kalınmamış, her bir disiplinin kendi araştırma alanına yakın şekli ile kavramsallaştırılan bir terim olarak literatür dahilindeki yerini almıştır. Zira, kent kavramını tek bir perspektiften değerlendirmek ve tek bir tanım üzerinde mutabık kalmak güç bir durum 
olmak ile birlikte kapsamlı ve yeterli de olamamaktadır. Pek çok disiplinin inceleme alanı olan kent ve türevleri kavramlarını, farklı bakış açıları ile irdelemek ve sorgulamak gereklidir. Kent kavramının, dinamik yapısı, değişken kimyası, devinimsel özellikleri, çok boyutlu nitelikleri ve etki alanının genişliği, kavramın her dönem sorgulanması gerekliliğini beraberinde getirmektedir. Kent olgusunun alt başlıklarından kentleşme, kentlileşme ve kentlilik bilinci kavramları, kültürlenme savı çerçevesinde çalışma dahilinde, saha araştırması metodu ile irdelenmektedir. Bu düşünceden hareketle, araştırmanın kuramsal ve kavramsal araştırması kentlilik bilinci bağlamında fenomenolojik araştırma metodu çerçevesinde oluşturulan sorular aracılığı ile sınanmaktadır. Yalova kentlilerinin, kentlileşme bilinçlerinin kentlilik kimlikleri bağlamında incelendiği çalışmada, Yalova kentinin kimliği ve yapısal öğeleri irdelenmektedir. Yalova kent kimliğinin kentlileşme, kentlilik bilinci ve kent kültürü oluşumuna etkileri, Yalova halkının kent kimliğini benimsemeleri ve kent kimliğine katkıları çalışma dahilinde ele alınmıştır. İlgili çalışma, alan araştırması niteliğini haiz olup, betimleyici öğeleri içeren bir tetkiktir.

\section{Araştırmanın Temel Problemi, Amacı ve Önemi}

Kentlilik kimliğine yönelik gerçekleştirilen tanımlamalar aracılığı ile Yalova kent kimliğinin araştırılması, Yalova kentlilerinin Yalova kentine dair aidiyet hissiyatları, kentlilik bilincine dair yönelişleri ve Yalova kentinin imgelenen (muhayyel) kimliğinin varlığına dair verilerin tespiti araştırmanın temel problemini oluşturmaktadır. Yalova kent kimliğinin tespiti ile birlikte, niteliklerinin ve öğelerinin de saptanması çalışmanın başat amacını teşkil etmektedir. Yalova kent kimliğinin izah edilmeye çalışıldı ğ araştırmada, Yalova kentlilerinin kentlilik bilincinin düzeyinin tespiti çalışmanın motivasyon kaynağını oluşturmaktadır. Kentlilik bilincinin varlığının kentlerin geleceği konusunda başat önem arz ettiği hususu çalışmanın kabulünü oluşturmaktadır. Bir kültür değişmesi olarak addedilen kentlileşme olgusunun, kentlilik bilincinin sürdürülebilirliği adına etkisinin yadsınamaz olduğunu ifade etmek gereklidir. Değişimlerden kaçınmanın mümkün olmadığı günümüzde, değişen bireysel ve toplumsal ihtiyaçlara yanıt verebilen kentlerin varlığı, kentleşme ve kentlileşme düze- 
yini de etkilemektedir. Günümüz bireylerinin ve toplumlarının kentlileşme bilincine erişebilmeleri adına kentlerin salt metropol haline dönüşmelerinin ve alt yapı hizmetlerini geliştirerek kalkınmalarının yeterli olmadığını ifade etmek mümkündür.

Yaşanılabilir kentlerin kalkınmalarının sürdürülebilirliğinin sağlanması ve sağlıklı yaşam alanlarının tesisi adına kentlilik bilincine sahip ve aidiyet hissiyatları gelişkin bireylerin, grupların ve toplumların sayılarının artırılarak, kentlileşme sürecinin sürdürülebilirliği sağlanmalıdır. Kentlerin büyüme, gelişme ve markalaşma süreçlerinde, kentlerde yaşamlarını sürdüren birey ve grupların kenti ve kent yapısını algılama biçimleri, kenti keşfetme motivasyonları, kentin doğal güzelliklerine dair geliştirdikleri farkındalık, kente dair oluşturdukları aidiyet hissiyatı, kenti ve değerlerini sahiplenme seviyeleri, kentin mevcut ve olası sorunlarına dair tutum ve davranışları, kent yönetimine ve kentsel kurumlara katılma edimleri, kent ile bütünleşme hissiyatları ve kentlilik bilinci olguları, kentlerin istikrarı ve yaşanılabilirliği adına büyük önem arz etmektedir. Yalova ilinin kentleşme, kentlileşme ve kentlilik bilinci olgularının saptanma ihtiyacının hissedilmesi, çalışmanın da önemini teşkil etmektedir.

\section{Araştırmanın Yöntemi}

Çalışma, bir alan araştırması niteliğinde yürütülerek, mevcut durumu saptamaya yönelik (saptayıc1), betimleyici bir araştırma şeklinde yürütülmüştür. Zira, olgular ve algılar bağlamında bir ilişki kurulabilmesi adına çalışmanın nitel araştırma yöntemi ile yürütülmesi kanaati oluşmuştur. "Nitel araştırma yöntemi bireylerin yaşam biçimlerini, hikayelerini, davranış tarzlarını, örgütsel yapılarını ve toplum ölçeğinde gelişen değişmeyi anlamaya yönelik bilgi üretme süreçlerinden biri" (Strauss ve Corbin, 1990, s.19) olarak nitelendirilmektedir. "Nitel araştırma yöntemi, kompleks, düzensiz, münakaşalı, pek çok yöntem ile araştırma konularının alanını oluşturur" (Punch, 2014, s.132). Bu sebeple nitel araştırma yöntemi, "bireylerin durum ve olgulara yükledikleri anlamları, farklı bir düşünce ile olayları ne şekilde nitelendirdikleri sorusuna yant aramaktadır (Dey, 1993, s.7). Araştırma ile Yalova kentine dair kentleşme, kentlileşme ve kentlilik bilinci olgularına dair genel bir tespit gerçekleştirilerek, kentin gelişiminin sürdürülebilirliğine dair mevcut verilerin genel görünümü bulgulanarak, 
betimlenmeye çalışılmıştır. Kentlilik bilinci kavramının alt başlıkları olan unsurlar, Yalova kent kimliği ve hemşehri kimliği bağlamında Yalovalılık kavramı ile irdelenerek, çalışma dahilinde saha araştırması aracılığı ile sınanmaktadır.

Çalışmada veri toplama tekniği olarak fenomenoloji tekniği kullanılmıştır. "Anlatı araştırması, fenomenoloji, kuram oluşturma, etnografi ve durum çalışması" (Creswell, 2013, s.6), olmak üzere beş tane araştırma desenini kapsayan nitel araştırma yöntemleri arasında fenomen niteliğini haiz, kentlilik olgusunu betimleyebilecek araştırma yönteminin fenomenoloji olduğu düşünülmektedir. Zira, nitel araştırma yaklaşımın benimsendiği çalışmada, kentlilik ve kentlilik bilinci kavramlarının bir fenomen şeklinde addedilmesi düşüncesi ile nitel araştırma metotlarından fenomenoloji deseninin elverişli olacağı düşünülmüştür. Fenomenoloji deseni, farkındalık oluşturan ve bu sebeple, sınanma ve irdelenme ihtiyacı hissedilen olguların derinlemesine analiz edilmesine fırsat tanıyan bir araştırma desenidir. Gerçekten de fenomenoloji deseni, kavramları, durumları, olguları, algıları ve olayları sorgulamak sureti ile detaylı araştırmaları olanaklı kılan nitel bir araştırma yöntemidir. Fenomen olarak addedilen bir olgunun derinlemesine irdelenmesine ve sorgulanmasına olanak tanıyan fenomenolojik yaklaşım, birçok bireyin farklı düşünce yapıları ile fenomen olarak tanımlanan olguya dair düşünce, deneyim ve algılarını öğrenme imkanını tanımaktadır. Bu yönü ile fenomenolojik desenin, "Bireysel deneyimleri evrensel nitelikteki bir açıklamaya indirgemeyi amaçlad1ğını" (Creswell, 2015, s.77), ifade etmek mümkündür.

Bu itibarla, çalışmanın odağını kentlileşme olgusunun oluşturduğunu ve kentlileşme bilincinin de fenomen olarak ele alındığını ifade etmek mümkündür. Bu sebeple, bireysel deneyimleri evrensel nitelikte bir aç1klamaya indirgenme çalışmasında, fenomenolojik bir tümevarım bulguları saptanmaya çalışılmıştır. Bu bağlamda "Kent Kimliği Göstergeleri Üzerinden Kentlilik Bilincine Dair Bir Okuma: Yalova Kenti Örneklemi" sorunsalının sınanması çalışmanın ana hedefini oluştururken, fenomene dair deneyimleri olan ve tecrübelerini çalışma adına gönüllü olarak paylaşma ön kabulü ile yaklaşan katılımcıların seçimi önceliklidir. Çalışma sürecinde her bir katılımc ile yaklaşık 45 dakikalık süreler dahilinde görüşülmüş̧ür. Nitel araştırmanın doğasına uygun olarak, katılımcıların verileri tekrar etme noktasına yaklaştıklarında, görüşme sonlandırılmıştır. 
Çalışma, fenomenolojik araştırma yönteminin yapısına uygun olarak, 2019 yılı Eylül, Ekim ve Kasım ayları olmak üzere, üç aya varan süre ile 5 katılımlı gözlem sürecini kapsamaktadır. Çalışma grubu ise, biyolojik yaşları 25-65 aralığında olan 5 erkek ve 5 kadın olmak üzere toplam 10 kişiden oluşmaktadır. Çalışma sürecinde kentlilik bilinci hissiyatının tespitine dair gönüllü katılımcların günlük yaşam pratikleri, kent ve kentlilik kavramlarını anlamlandırma motivasyonları, kentlileşme edimine dair geliştirdikleri alışkanlıkları ve ilgili refleksten hareketle kentlileşme süreçleri bulgulanmış ve incelenmiştir.

\section{Araştırmanın Evren ve Örneklemi}

Kentlilik bilinci kavramının tanımına koşut olarak addedilen unsurlar, kentleşme ve kentlileşme bağlamında incelenmiştir. Birey ve toplumların kente uyum motivasyon ve davranış kalıplarının belirlenmesine yönelik sorunsalın sınandığı çalışmanın evrenini, 15 yıl ve üzeri süre ile Yalova kent merkezinde ikamet eden ve kentlilik bilinci yaklaşımını benimsedikleri düşünülen, Lisans ve üzeri eğitim düzeyinde ölçeklenen, yaşları 25 ve 65 arasında değişkenlik gösteren, erkek ve kadın popülasyonu ve örneklemini de 10 kişi oluşturmaktadır. Örneklemi oluşturan katılımcılar, “yaşadıklarını paylaşabileceği bir yabancıya ki burada ilgili kişi araştırmacıdır, güvenip açılabilirse, kendisi gibi başka kişilerin de araştırmacı ile bağlantı kurmasını sağlayabilirler (Punch, 1998, s.58). Araştırmanın evrenini oluşturan Yalova kentinin Merkez ilçesinde ikamet eden katılımcıların, gönüllülük ön kabulü ile katılımları amaç edinilmiştir. Fenomenoloji deseninde, araştırmanın katılımcılarını belirlemek, çalışmanın fenomenine bağlı olarak farklılıklar arz etmektedir. Yalova kenti, nüfus popülasyonu olarak farklı bölgelerinde, farklı karakteristik niteliği haiz, farklı yapılanmaların söz konusu olduğu çokkültürlü bir kimliğe sahiptir. Yalova kentinde ikamet eden ve örneklemi teşkil eden bireyler araştırmanın saha kısminı oluşturmaktadır.

Yalova kentine dair hissedilen aidiyet ve kentlilik bilincinin ölçülmesine dair detaylı soruların oluşturulduğu çalışmada, Yalova kent kimliğinin belirlenmesi üzerine bir araştırma gerçekleştirilmiştir. Araştırma sürecinde örneklem tesis edilirken, amaçlı örneklem yönteminin kullanımı 
uygun görülmüştür. “Amaçlı örnekleme, araştırmacının keşfetmek, anlamak, iç görü kazanmak istediği ve çoğu şeyin öğrenebileceği bir örneklem seçiminin zorunlu olduğu varsayımına dayanır" (Merriam, 2013:76). Amaçlı örneklem metodu, olasılık kuramı ile temellenen nicel örneklem metotlarının zıttı bir yapı sergileyerek, araştırmanın kapsamına dahil olan olay, olgu, kişi, durum ve obje hakkında belirli bir amaç doğrultusunda derinlemesine bilgi edinme motivasyonunu taşıyan bir metottur. Bireylerin ve grupların güncel yaşam pratiklerini doğal ortamlarında gözlemleme imkanı tanıyan amaçlı örneklem yöntemi, farklı yaşam koşullarını ve farklı bakış açıları ile farklı kişisel özellikleri yansıtacağından, çalışmayı da zenginleştireceği kanaati edinilmiştir. Bu sebeple, çalışmanın verimliliği adına amaçlı örneklem metotları arasından azami çeşitlilik örneklemesi kullanılarak, katılımcıların seçiminde farklı niteliklere sahip bireylerden oluşan bir çalışma grubu tercih edilmiştir. Zira ilgili tercih, araştırmanın sorunsalı konusunda ortaya çıkan farklı görüşlerin niceliğini de artıracaktır. Çalışma kapsamına dahil olan katılımcıların taraflarına yöneltilen soruları doğru şekilde anladıkları ve yanıtladıkları sayıltılanmıştır.

\section{Araştırmanın Veri Analizi ve Bulgular}

Belirtilen veriler ışığında gerçekleştirilen araştırma kapsamında, katılımcların gönüllülük esasına dayanan katılımları ön kabulü ile oluşturulan çalışmanın soruları, yarı yapılandırılmış soru formunda şu şekilde yer almakta olup, araştırmanın verilerini de yarı yapılandırılmış forma bağlı olarak aşağıdaki şekilde gruplandırmak mümkündür.

\section{Yalova kentinde yaşama (bulunma) nedenine yönelik veriler;}

- K.1: Devlet memuruyum, tayinim 15 yıl önce Yalova'ya çıtı, ilk yıl biraz zorlanmıştım, ama çok kısa sürede alıştım, küçük bir şehir, yaşam büyük şehirlere göre daha rahat, huzurlu ve sakin. Yaşamak için de özellikle tercih ettiğim bir şehir, büyük kentlerin keşmekeşinden uzak olması büyük bir avantaj. Şehri ilk gezdiğimde doğası ile ortamı ile yaşanılabilir bir kent olduğunu düşündüğüm için tercih etmiştim. 
- K.2: 19 yaşımda babamla çalışmak için geldiğim şehir, burada evlendim, memlekete dönmek istemedim, çocuklarım da Yalova'da yaşıyor, yaşım 64, emekliyim, büfem var, çalışıyorum.

- K.3: Bursa doğumluyum, Yalova'ya gelin geldim, arazimiz var, çiçek işi ile uğraşıyorum, artık bu şehrin yerlisi olduk, başka bir yere gitmeyi hiç düşünmedim.

- K.4: Yalova doğumluyum, lisansı Ankara'da bitirdim, ailemin yanına döndüm.

- K.5: Tayinim Yalova'ya çıkmıştı, birkaç yıl sonra da emekli oldum, yerleştim.

- K.6: Üç göbek Yalovalı'yız, dedem gelmiş, okumadım, babamın dükkanını devraldım, baba mesleğine bu şehirde devam ediyorum, Yalova'dan evlendim, güzel şehir, zorlukları da var.

- K.7: Yalova doğumluyum, o zamanlar Yalova şehir değildi, ailem, akrabalarım hepimiz buradayız, başka şehirlere gitmek istemedim, çocuklar İstanbul'da okuyor.

- K.8: Yalova'da doğdum, başka bir memleket bilmem, mis gibi ama zor şehir, pahalı şehir.

- K.9: Yerlisiyim, Yalova doğumluyum, gitmeye çok çalıştım ama hayat şartları kaldım.

- K.10: Ailem babamın işi için gelmiş, ben çocuktum, Yalova'da olmak güzel.

\section{Yalova kentine dair akılda kalan öğelere yönelik veriler;}

- K.1: Yalova kaplıcaları ile Yürüyen köşkü ile plajları ile temiz havası ve birbirinden güzel çiçekleri ile anılır. Bir de kivisi güzeldir. Termal ilçesi ve termal turizmi, Çınarcık, Armutlu ve Esenköy birer turizm cenneti. Yalova'da kamp ve ören yerleri ile şelaleler daha iyi tanıtılabilir.

- K.2: Bizim şehrimizin her şeyi güzel. Atatürk'ün şehridir Yalova, modern, çağdaş, bereketli.

- K.3: Zanaatım çiçekçilik, çiçeklerimiz güzeldir. Denizimiz, kaplıcalarımız, lezzetli meyvelerimiz var. Ama en güzeli Yürüyen Köşkümüz var, bize Atam'dan miras kaldı. 
- K.4: Her ne kadar insanların aklına ilk olarak Yalova ile ilgili kaplıcalar gelse de kentimiz her türlü doğal güzelliğe sahiptir, denizimiz güzeldir, İstanbul'un banliyösü olması da avantaj.

- K.5: Yalova denince ilk akla gelen Kaplıcaları oluyor ama Yalova çiçekler diyarı bir kent, Yürüyen Köşkümüz var, Erikli Yaylası, Sudüşen Şelalesi, Arboretumu ile yaşanılası bir şehir.

- K.6: Yalova denizi, tarihi güzellikleri ve Yürüyen Köşkü ile akla gelir.

- K.7: Yalova yazlıkları ile ünlü sanırım. Denizi, organik ürünleri ve kaplıcaları ile de ünlüdür.

- K.8: Yalova artık büyük şehirlerden kaçıp sığınılan bir yer olarak anıl1yor. Huzurla tatil yapmak akla gelir, kaplıcaları akla gelir, çiçekleri akla gelir. Bir de Yürüyen Köşkü akla gelir.

- K.9: Şehrimiz, kaplıcaları, çiçekleri, turistik mekanları, tarihi güzellikleri ile anilır.

- K.10: Çiçek cennetidir kentimiz, kaplıcaları, denizi, yeşili, organik ürünleri ile ünlüdür.

Yalova kentini tanıma ve farkındalık (tarihi, kültürel ve coğrafi özellikleri ile) dïzeyine yönelik veriler;

- K.1: Yaşadığım şehri iyi tanırım, hemen hemen her yerini gezdim. Doğal güzelliklerini sık sık gezerim, kentimde olan her bir gelişmeyi takip ederim, ulaşım imkanı anlamında da elverişli. Yalova özellikle doğa ve turistik güzellikleri ile gerçekten hak ettiği yere gelememiş bir kenttir. Belki emsali olan bazı kentler ile tarih noktasında yarışamayabilir ama Mustafa Kemal Atatürk'ün benim kentimdir dediği bu şehir, doğa ve turistik özellikleri ile hak ettiği yere henüz gelememiş bir şehirdir.

- K.2: Eskiden daha tenha bir şehir idi, artık daha kalabalık bir şehir. Ama her hali ile güzel, kentimi tanırım, yeniliklerini takip ederim, her yerini de gezdim, firsat buldukça da gezerim.

- K.3: Yalova gün geçtikçe gelişen bir şehir, insanı iyi, her milletten insan yaşar, sıkıntıları da olur ama büyükşehirlere yakın olan küçük güzel bir şehirdir, şehrimi iyi takip ederim.

- K.4: İşim gereği zaten ilçeleri gezmek durumundayım, o sebeple kentin ana mekanlarını bilirim, gelişmeleri takip ederim, turistik şehrimize her 
geçen gün ilginin artığını gözlemliyorum. Güzel gelişmeler de oluyor, doğal güzellikleri görülmeye değer bir şehir.

- K.5: Sağlık çalışanı idim, kentin her ilçesinde görev yaptım, şimdi emekliyim, tarihi ve kültürel gezileri mütemadiyen yapıyorum, kentimiz gelişiyor, seviniyorum.

- K.6: Restoran işi yapıyorum, işyerimden pek fazla ayrılamıyorum, ama izin zamanlarımda şehrin güzelliklerini değerlendiriyorum, Yalova'yı iyi bilirim, insanın tanırım.

- K.7: Büyükşehirlere yakın olduğumuz için ziyaretçimiz çok olur. Şehrin yerlilerini de tanırım. Sokaklarını karış karış bilirim. Güzellikleri olduğu kadar zorlukları da var, şehrimi tanırım.

- K.8: İşim toplu taşıma. Bir minibüsüm var, o yüzden her yerini gezerim, takip ederim, insan sirkülasyonu da çok olunca, nerede ne olmuş hemen haberim olur. Fark ederim.

- K.9: Giyim mağazası çalışanıyım, çalışma saatlerim uzun olur, yine de iş çıkışı şehirde şöyle bir tur atmayı severim, merkezde olduğum için gelişmelerden de haberim hemen olur.

- K.10: Otel personeliyim, müşteriler kentin doğal güzelliklerini sever, deniz turizmi iyidir, sordukları sorulara cevap vermek için zaten takip etmek zorundayım. Şehri iyi tanırım.

\section{Yalova kentinin, kent olma özelliğini taşımasına yönelik veriler;}

- K.1: Çok çeşitli insanlar yaşar Yalova'da, farklı etnik kökenler vardır, kimse de sorun yaşamaz, ticarette gelişiyor, turizmde gelişiyor, sanayi alanında da gelişse çok güzel olur, kent olma özelliğini fazlası ile taşıyor, şehrimizde hemen her türlü olanağa sahibiz. Ancak kişisel tercihim sorulur ise il olmak Yalova'yı kalkındırmamış, İstanbul'un bir ilçesi olarak kalsa idi daha çok olanaklara sahip ve kalkınmış bir konumda olurdu. Gerçekçi olmak gerekir ise Türkiye'nin en büyük ekonomik gücüne sahip kenti ve yerel yönetimi olan İstanbul'un köyü durumundaki birkaç yerinin, Yalova'nun il olduğu dönemde dahi Yalova'dan on kat daha fazla gelişmiş ilçeler haline geldiklerini ve Yalova'ya göre turizm anlamında pek çok dezavantajları olmasına rağmen daha fazla tanınır olduklarını görmemiz gereklidir. Bunun temel ve can alıcı noktası tabi ki ekonomik güçtür. 
- K.2: İstanbul ve Bursa'dan epey etkilenen bir kent, Yalova kent de biz kentlileşemedik.

- K.3: Şehrimiz kent olma özelliğini taşır, kültür varlıkları ile insanı ile keyifli bir şehirdir.

- K.4: Ülkemizin kentleri arasında ilk on siralamasına girebilecek bir kenttir.

- K.5: Kent olma özelliklerini taşır, çok özelliği vardır şehrimizin, her yaş grubundan insan için çekiciliği vardır, iş imkanları biraz daha olumlu olsa kimsenin göç edeceğini düşünmüyorum.

- K.6: Yaşam kalitesi adına güzel bir kenttir, pahalıdır, biraz daha elverişli şartlar olsa ismini daha ön plana çıkarıp, marka olabilecek bir şehirdir. Her dokudan insan yaşar, kozmopolittir.

- K.7: Son 10 yıllık dönemde kasaba görünümünden kent durumuna geçtiğimizi düşünüyorum.

- K.8: Modern bir kent olduğumuzu düşünüyorum, eksiklerimiz var, ama zamanla turizmin ve kültürün cazip kentlerinden biri olacağımızı düşünüyorum.

- K.9: Yalova işsizlik ve trafik sorunlarını aşamasa da kent niteliğini kazanan doğa harikası bir yerleşim yeridir. Farklı etnik kökenler huzur içerisinde yaşar. Ancak çok pahalı bir şehirdir.

- K.10: Turizmi, doğal güzellikleri, tarihi özellikleri ve kültürel yapıları ile kent özelliğindedir.

\section{Yalova kentinde yaşam ile mutluluk ilişkisine yönelik veriler;}

- K.1: Yalova'nun temel birkaç problemi var, işsizlik, pahalılık ve trafik en büyük üç sorunu. Üç sorun hafifledikçe mutlu insanların oranı da artacaktır.

- K.2: Yalova çok güzel bir şehir ama pahalı bir şehir, geçim kaygıları ile her şehirdeki insan ne kadar mutlu ise Yalovalılar da o kadar mutlu. Ama her şeye rağmen huzurlu bir şehir.

- K.3: Yalova'da yaşamak insana huzur veriyor ama şartlar daha iyi olsa daha güzel olur.

- K.4: Yavaş bir şehir, kışın daha da yavaşlıyor, sosyo-ekonomik imkanlar artıkça, mutluluk oranı da artacaktır, istihdam yaratılmalı, şehrin sorunlarına çözüm aranmalıdır. 
- K.5: Yaşanabilir bir kent, aşırı kalabalık değil, kentte mutlu olabilecek daha fazla vakit yaratmak mümkündür, denizi var, termal turizmi var, yüzde yetmişi orman olan doğa ile barışık bir kent, çevre illere ulaşımı kolay olan, merkezi konumda, iklimi ve sosyal hayatı ile canlı, pek çok olanağ 1 ile herkesi mutlu edebilecek bir kenttir.

- K.6: Bir ucundan diğer ucuna bir saatte ulaşabiliyorsunuz, günümüzde mutluluk ekonomi ile orantılı olmuş, geliri iyi olan her yerde olduğu gibi kentimizde de daha mutludur.

- K.7: Canlı bir şehir, yaşayan bir şehir, imkanlar arttıkça mutluluk da artar.

- K.8: Maddi kaygılarınız yok ise yaşamak için Yalova'dan daha keyifli bir şehir bulamazsınız. Zaman zaman zorlansam da bu kentte yaşamaktan mutluyum.

- K.9: İstihdam yaratılır ise mutlu olunmayacak bir kent değil, bu şehri seviyorum, mutluyum.

- K.10: Tarihi ve kültürel yapısı ile güzel bir şehir, insanları da iyidir, yaz ayları çok kalabalık olur, genel olarak mutluyum, ama zorlandığım konular da çok olur, yine de severim.

\section{Kendilerini Yaloval olarak (kentsel aidiyet) tanımlama motivasyonuna yönelik veriler;}

- K.1: Bu kenti seviyorum, çünkü kendimi bu şehirde rahat hissediyorum, pek çok avantajı var, dezavantajlarını da tolere edebilecek güzel bir yaşam sunuyor, bu sebeple kendimi bu kente ait hissediyorum.

- K.2: Tanımlarım, ihtiyacım olan her şeye kısa zamanda erişirim. Kentin yapisinı seviyorum.

- K.3: Yalova'dan başka bir şehre gittiğimde özlerim, bir süre sonra Yalova'ya dönmek isterim.

- K.4: Bu kentte mutluyum, bana huzur verir, alıştı̆̆ım bir yaşantım var, aidiyetim vardır.

- K.5: Çok arkadaşım, akrabam bu kentte, bu kente dair yaşanmışlıklarım çok fazla. O yüzden bu kentten ayrılmam zor, zaman zaman İstanbul'a gözüm kayar ama yine de Yalova başkadır.

- K.6: Büyükşehirlerin keşmekeşini görünce kendimi Yalova'ya dar atarım, iyi ki bu şehirde yaşıyorum derim, tabi aidiyetim vardır, bu şehirde yaşıyorum. Aksaklıkları yok değil. 
- K.7: İnsan yaşadıkça daha çok seviyor bu şehri, huzurlu ve sakin bir kent, sosyal yaşamı biraz daha hareketli olabilir, ancak yine de rahat bir şehir, Yalova'ya ait hissederim.

- K.8: İmkanı çok olan ama iyi değerlendirilmesi gereken bir şehirdir Yalova, bu kadar tabiat zengini bir kenti sevmemek mümkün değil, severim ait de hissederim.

- K.9: Yalova' da özgür yaşarsınız, insanları çağdaştır, göçmenlerin az olmasını tercih ederdim, eskiden daha da güzeldi, Araplar bizleri bir nebze zorlasa da severim, benim kentim, bana ait.

- K.10: Zaman zaman İstanbul'da yaşama hayalim olsa da yine de dönüp dolaşıp geleceğim yer Yalova, bu şehir bir şekilde kendini çekmeyi başaryyor, ait hissederim, severim, korurum.

\section{Yalova kentinde mevcut gelişmelerin takip edilmesine (farkındalı) yönelik veriler;}

- K.1: Tabi ki takip ediyorum. Hem yerel basından hem de sosyal medyadan ayrica bu kente kendini ait hisseden bir kentli olarak her türlü sosyal ve kültürel gelişimi takip ediyorum ve edebiliyorum da bu türlü imkanları bu şehir için yeterli görüyorum.

- K.2: Evet, takip ederim, küçük şehir zaten en ufak bir gelişmeyi tüm kent sakinleri hemen duyar. Yerel basını da takip ederim, gözlemlerim, değişiklikleri hemen fark ederim.

- K.3: Yerel yönetimlerimiz iyi çalışıyor, bizleri de sıklıkla haberdar ediyorlar.

- K.4: Daha çok yapılması gereken iş var, ancak yenilikleri de fark ederiz, Yalovalılar kentini takip eder, nerede ne olmuş biliriz, yaşadığımız şehir sonuç itibariyle, bilmemiz de lazım.

- K.5: Yerel basınımız kuvvetlidir, hemen her gelişme adına bizleri bilgilendirirler zaten küçük ölçekli bir şehir olduğundan takip etmek zor değil, ilgimi de çeker, araştırır, öğrenirim.

- K.6: Takip etmek için özel bir çaba harcamam, ama haberim olur, eş dost birbirine anlatır.

- K.7: Yalova sahip olduğu olanaklar ile daha çok gelişmelerin yaşanması gerektiği bir şehir, takip ederim, günümüzde zaten kim ne yapsa hemen ilan ediyor, sosyal medyadan öğrenirim. 
- K.8: Eski zamanlardaki halini de bilirim, günümüzü de takip ederim, ters bir gelişmede tepki de gösteririm, insanları uyarırım, yerel yönetimlere başvururum, şehrime özen gösteririm.

- K.9: Yalova insanı bilinçlidir hemen herkes gelişmeleri takip eder, ben de ederim.

- K.10: Şehrini seven zaten takip eder, etmese de Yalova'da mutlaka öğrenir, duyar.

\section{Yalova kent faaliyetlerine dair gönüllülük motivasyonlarna (kent kurumla-} rına katılım) yönelik veriler;

- K.1: Tabi ki gönüllüyüm, şehrin kalkınması ve gelişmesi adına bu kente aidiyet hisseden biri olarak bu kente katkı sunmaya hem gönüllü olmaya hem de elimi taşın altına koyup sorumluluk almaya da hazırım.

- K.2: Çalışma saatlerim çok uzun olduğu için zaman bulamasam da yine de kentim için katkı sağlamak isterim, 64 yaşındayım, gençliğimde daha aktif rol alırdım.

- K.3: Derneklere üyeliğim var, kent konseyimiz de çok iyi çalışıyor, fırsat buldukça gönüllü çalışmalara katılmak isterim, kent bizim, ömrümüz bu kentte geçiyor.

- K.4: İşim yoğun olduğu için çok firsat bulamıyorum ama annem ve babam kent yönetiminde epey aktif rol oynuyorlar, ailemde kentimiz için gönüllü çalışan çok sayıda büyüğüm var.

- K.5: Emekli adamım, genç emeklilerden, yaşım 55. Kentim için pek de çalıştığım söylenemez ama aslında şimdi eksikliğimi fark ettim, ben de çalışmalara katılmalıyım.

- K.6: Restoran işlerimden pek firsat bulamıyorum ama ben daha çok gönüllü olarak hayvan barınakları konularında gönüllü çalışıyorum, çevremi temiz tutuyorum, elimden bu geliyor.

- K.7: Güvenlik görevlisiyim, çalışma saatlerim uzun, ama kardeşlerimin derneklere ve etkinliklere üyelikleri var, ben de isterdim ama hayat şartları zor, ekmek önce geliyor.

- K.8: Minibüs şoförüyüm çalışma saatlerim uzun, ama kent yönetimine bu şehirde ulaşmak kolay gerçekten, bir derdimiz olduğunda ulaşıyoruz, ama vatandaş olarak yapabileceğimiz bir şey olduğunda geri durmuyoruz, kentimiz için, vatanımız için ne gerekirse yaparız. 
- K.9: Mağazada uzun saatler çalışıyorum ama yine de kentim ile ilgili bana düşen bir görev olduğunda seve seve üstlenirim, önceki yillarda da görev almıştım.

- K.10: Otelimiz zaten birtakım konularda görevler alıyor, biz de kentimize dair bir vazife olduğunda çekinmeden görev aldık, alırız da. Bu şehir bizim, hepimizin.

\section{Yalova kentine dair geliştirilen sosyal ve duygusal bağlarn (kenti sahip-} lenme) varliğına yönelik veriler;

- K.1: Tabi ki sahipleniyorum, çünkü ben bu şehirde yaşıyorum. Bu şehirde yaşayan biri olarak, her türlü kültürel ve sosyal gelişimine katkı sağlamak şehri daha tanınabilir ve daha iyi bir seviyeye taşımak için elimden geleni yapmaya hazırım.

- K.2: Bazen insanların birçok konuda duyarsız olduğunu görünce içim acıyor, kent bizim, elbette sahiplenirim, daha güzel bir kentte yaşamak hepimizin hakk1, sosyal çevrem bu kentte.

- K.3: Sosyal biriyim, tanıdığım var, çok arkadaşım var, Yalova ile özdeşleşen çok hatıram var, kenti sahiplenmek demek hatıraları da sahiplenmek demektir.

- K.4: Çocukluğum bu kentte geçti, Yalova demek çocukluğum demek, elbette kentimi sahipleniyorum, seviyorum, gençliğim bu kentte geçiyor.

- K.5: İnsanın yaşadığı yer kıymetlidir, bu kentte yaşıyorum, bu yüzden tabi kentimi sahiplenirim, daha güzel olması için çabalarım, herkes de çabalamalı gerçekten.

- K.6: Ne anılarım var bu kentte bir bilseniz, bu kentte aşık oldum, bu kentte dayak yedim, bu kentte mutlu oldum, ekmeğimi bu kentten çıkaryyorum, tabi sahipleniyorum, benim kentim.

- K.7: İnsan psikolojik olarak yaşadığı yerde mutlu ise yaşadığı kenti sahiplenir, mutsuz ise terk etmeye çalışır, ben bu kentte iyiyim, mutluyum, güzel zamanlar yaşadım, sahiplenirim.

- K.8: Bu şehrin her sokağında her köşesinde yaşanmışlı̆̆ım var, kenti seviyorum, ama çok pahalı bir kent, geçim derdi olmasa insanlar daha da çok sahiplenir, başka şehirlere gitmeye çalışmaz, maddi olarak yeterli olan biri bu güzelim şehri bırakıp neden gitsin? Sahiplenir. 
- K.9: Kentimiz güzel, tabi sahiplenirim, çocuklarım burada büyüdü, akrabalarım, sosyal çevrem burada, hali ile duygusal bağ da oluşuyor, başka yerlere gittiğimde şehrimi özlerim.

- K.10: Kentimiz güzel, yaşadığım şehri seviyorum, imkanım olur ise daha güzel semtlerine taşınmak istiyorum, insanı da iyidir, duygusal olarak da bağlıyım kentime, sahiplenirim.

\section{Yalova kentine dair mevcut olumsuzluklar karşılama biçimlerine (kente karşı sorumluluk) yönelik motivasyonları;}

- K.1: Yalova küçük ve güzel bir şehir olmasına rağmen bazı sorunlarına kalıcı çözümler bulunamıyor. Bunlardan birkaçını saymak gerekir ise birincisi şehrin ulaşım arterlerini yazın oluşan yazlıkçı ve turist trafiğine bir çözüm üretilmesi gerekiyor, bu da hem yerel yönetime hem de merkezi yönetimin erklerine düşüyor, çünkü yakın zamanda yapılan İstanbul-İzmir otoyoluna Yalova merkezinden il çevre düzeni planında planlanmış olan çevreyolu ne yazık ki henüz başlatılamamıştır. Bu konuda gerekli ciddiyet oluşturularak, konunun en kısa süre içerisinde çözülmesi gerekmektedir. Şehrin bir diğer temel sorunu da kentin tanınabilirliğinin artırılması adına daha çok reklamının ve tanıtımının yapılması noktasında çalışmalar gerçekleştirilmelidir. Üçüncü önemli sorunu da şehrin deprem riskinin düşünülerek, ciddi bir kentsel dönüşüme ihtiyacı olduğudur.

- K.2: Yaşadığım en büyük sorun pahalılık, Yalova'ya benzer şehirlerde bu derece pahalılık yok, maddi kaygım olmasa daha rahat olurdum, 64 yaşında çalışmak zorunda kalmazdım.

- K.3: Her şehrin kendine göre zorlukları var, Yalova'nın da var, ama biraz daha gelişmesi gerekiyor, bu kadar doğal güzelliği olan bir kentin en az Kocaeli, Sakarya ve Bursa kadar gelişmiş olması gerekirdi, deprem riski beni korkutuyor, şehir planlama işinin ciddiyetle yapılması gerekiyor, 1999 depreminden sonra aslında pek de düzelme olmadı, korkuyorum.

- K.4: İşim gereği devlet dairelerinde mesaiyim çok oluyor, bir işimi çözene kadar nerede ise tüm kenti gezmiş oluyorum, her bir devlet dairesi birbirlerinin zit noktasında bu da ben ve benim gibileri çok yoruyor, tek bir alanda olsa, insanların işleri kolaylaşsa ne güzel olur. 
- K.5: Biz yine bir şekilde geçimimizi sağladık, çocukların uzak şehirlere gitmesini pek istemiyorum ama bu şehirde iş bulmak da zor, yeni istihdam alanları yaratılmalı, çok iyi olur.

- K.6: Yalova çok güzel bir şehir ama gelir adaletsizliği var, hayat pahalı. İmkanı olan için güzel şehir ama yine de insan kopamıor, şehir gelişsin, kalkınsin istiyorum.

- K.7: Trafik ve otopark sorunlarına yıllardır bir çare bulunamadı. Yerel yönetimler çalışıyorlar ama çözüm bulsalar herkes rahat edecek. Yazık, çok zorlaniyoruz.

- K.8: Daha düzenli bir şehir olmalı, daha planlı olmalı, çok dağınık bir şehir, küçük olduğu için bir şekilde çözüyoruz ama sistemli olması vatandaşı daha çok mutlu ederdi.

- K.9: İş imkanları biraz daha iyi olsa, şehir biraz daha ucuz olsa herkes daha rahat ederdi, bizim seviyemizde bir şehrin çok daha gelişmiş olması gerekirdi.

- K.10: Daha çok iş imkanı yaratılmalı, pahalılık azaltılmalı, trafik ve otopark problemleri çözülmeli, deprem için tedbir alınmalı, depremi unuttuk. Yarın bir deprem olsa 1999 depreminden daha fazla zor durumda kalacağız. Eksikleri var ama bir şekilde öteleniyor.

\section{Sosyal çevre bilinci edinme hissiyatına yönelik veriler;}

- K.1: İnsanın sosyal bir varlık olduğunu düşünür isek her şeyin ev-iş yaşantısı olmadığından yola çıkarak, insanların sosyal sorumluluk projelerinin içerisinde yer alarak, şehirdeki kültürel faaliyetlere katılım sağlayarak ve destek vererek, bunları daha cazip hale getirmeleri gerektiği kanaatindeyim. Ayrıca, şehrin kültürel yaşantısının daha da renklenmesi adına hem fiziki alanların artırılması hem de daha çok insanın katılabilmesi için doğru tanıtılması gerektiğinin düşüncesindeyim.

- K.2: Yazın hali ile daha kalabalık oluyor, daha çok etkinlik oluyor, kış aylarında sahil kasabası gibi oluyor, biz yine çay bahçelerinde zaman geçiriyoruz ama gençler için daha çok imkan yaratılmalı, sosyal etkinlikler çoğalmalı, kültürel etkinlikler şehrimizde az.

- K.3: Tiyatro etkinliklerimiz az, opera ve baleyi de gönül ister, festivaller artırılmalı, benzeri nüfusa sahip pek çok şehir sosyal anlamda daha etkindir. Kıskanıyoruz. 
- K.4: Şehrimiz aslında pek çok imkana sahip ama yeterince değerlendirilmiyor, daha etkin çalışmalar gerçekleştirilmelidir, Yalova aslında çok uzun süre önce marka bir şehir olabilirdi.

- K.5: Çocuklar sürekli İstanbul'da etkinlik kovalıyor, bizim şehrimizde daha çok etkinlik olsa daha güzel olur, çocuklar gözümüzün önünde sosyalleşirler. Şehir için de iyi olur.

- K.6: Şehirde eşimiz, dostumuz, çoluk çocuğumuz güvenle sosyalleşebiliyor, aklımız kalmıyor, farklı kültürden pek çok insan demokratik şartlarda yaşayabiliyor, daha da etkin sosyal etkinlikler düzenlenmelidir, biz başka şehirlere etkinlik için gitmemeliyiz, başka şehirlerden bizim etkinliklerimiz için gelmeliler. Her türlü alt yapımız var.

- K.7: İnsanlar sıcak kanlı bu şehirde, kışın birbirimizin evlerine gidiyoruz, yazın hepimiz bahçelerde ve sokaklarda oluyoruz. Bazı mekanlar pahalı, ücretsiz alanları ve etkinlikleri çoğaltırlar ise şehirdeki insanların da sosyalliklerini artırmış olurlar.

- K.8: Bizim gibi işi dışarıda olanlar zaten her zaman sosyal ama bizler için fiyatı uygun güzel mekanlar ve etkinlikler düzenlenmeli. Halka uygun alanlar çoğaltılmalı.

- K.9: Yerel yönetimler halk ile yakın temas halindeler, aslında sosyal mekanlar için de çalışıyorlar ancak süreç çok uzun sürüyor, tabiat güzellikleri daha iyi değerlendirilmeli, halka ücretsiz daha fazla etkinlikler sunulmalı.

- K.10: Sosyalleşmek insanlar için bir ihtiyaç, konserler, dinletiler, yarışmalar, spor müsabakaları yapılmalı, halka daha fazla imkan sağlanmalıdır.

\section{Kent aktivitelerine katılım hassasiyetine yönelik veriler;}

- K.1: Kent aktivitelerine mümkün mertebe katılmaya çalışıyorum ancak tanitımlara hem yerel medyada hem de sosyal medyada ve dahi diğer reklam argümanlarında daha fazla yer verilmesi gerektiğini düşünüyorum.

- K.2: Belirli etkinliklere katılmaya çalışıyorum ama büfeyi bırakmam zor oluyor.

- K.3: Bilinçlenme adına konferanslar düzenlendiğinde katılmaya çalışıyorum, Üniversite'nin halka yönelik etkinliklere destek vermesi gerekiyor, güzel etkinlikler olduğunda katıllyorum. 
- K.4: Basın mensubuyum, haber yapmak adına birçok aktiviteyi takip ediyorum, ama işim gereği olmasa bile kaliteli etkinliklere katılmaya çalışırım, çevremdeki insanlar da katılır.

- K.5: Emekli adamım, elimden geldiğince bilgim olan her aktiviteyi takip etmeye çalışıyorum.

- K.6: İsyerinden uzun süre ayrilamasam da yine de dinlenmek ve kafamı dağıtmak için etkinliklere katılırım, eşimi, çocuklarımı ve ailemi de gönderirim, güzel olur, farklı olur.

- K.7: Güvenlik görevlisi olarak zaten epey etkinliklere katıliyorum, ama firsat buldukça beğendiğim etkinlikleri izin günlerinde de takip ediyorum. Daha çok etkinlik olmalı.

- K.8: Halkımız duyarlı, güzel etkinlik olsun herkes firsat yaratıp katılmaya çalışır. Ama pahalı etkinlikler olduğunda geri durabilir, herkesin kazancı ayn değil. Maddi duruma bağlı olarak etkinliklere katılım değişebilir, sonuçta önce insan karnını doyuracak sonra sosyalleşecek.

- K.9: Çalışma saatlerime uyan her etkinliğe katılmaya çalışıyorum, benim için değişiklik oluyor. Çevremdeki insanlar da etkinliklere katılmaya çalışıyor, yeter ki kaliteli olsun.

- K.10: Kente dair etkinlikleri bizim halkımız takip ediyor, Valilik logo yarışması düzenledi, çok sayıda başvuru oldu, fotoğraf yarışması düzenlendi, çok kişi katıldı, farklı etkinliklere de insanımız rağbet ediyor, Üniversite de şehrin etkinliklerini desteklemeli, her yaştan insana göre etkinlikler kategorize edilmeli, herkes katılabilsin. Ücret de önemli bir faktör tabi ki.

Bir sorun ile karşılaşıldığında yerel yönetimlere erişme (iletişim kurma) olanaklarna yönelik veriler;

- K.1: Yalova yerel yönetiminin bu konudaki çabalarını görüyorum. Ancak bu çabaları yine de yeterli görmüyorum. Yalova yerel yönetiminin halkla daha fazla iç içe olması gerektiğini düşünüyorum. Bu konuda naçizane Yalova yerel yönetimine bir önerim olacak ise sosyal medyayı daha çok kullanmaların tavsiye ediyorum.

- K.2: Uzun yıllardır bu şehirde olunca, çok kişiyi tanıyoruz, yerel yönetimlerde dostlarımız oluyor, ama Valilik personeli de ilgili, bir sorun olduğunda hemen ulaşabiliyoruz. 
- K.3: Yerel yönetimimiz ilgili, haklarını yiyemem, sorunlar hemen çözülmese de en azından muhatabımız olduğunu biliyoruz, mutlaka derdimizi anlatabileceğimiz bir merci oluyor.

- K.4: Yerel yönetim mensupları halkımız ile iç içe, sokakta yürürken görüyoruz, yemek yediğimiz restoranda karşılaşıyoruz, yanlarına dahi gitsek dinlememezlik etmezler.

- K.5: Yönetim mensupları şehirlilere karşı ilgili, haklarını teslim etmek lazım, ama şehrin çok eksiği var, onlar da haklı hangi birine yetişsinler, zamanla daha güzel olacağına inanıorum.

- K.6: Şehir küu̧ük olduğu için birilerine ulaşmak rahat oluyor, biraz yavaş işliyor ama günün sonunda muhatap bulduğumuzu söylemem lazım. Yerel yönetimimiz ilgilidir.

- K.7: Valimiz ile görüşmek isteseniz bile randevu alabilirsiniz, hemen olmaz ama sizinle ilgilenmeden yerel yönetim yöneticilerinin kapılarından dönmezsiniz. İlgililer, takdir ederim.

- K.8: İlaki ulaşıyoruz, telefonla da arasak, kurumlara da gitsek mutlaka bir muhatap buluyoruz, nüfus çok yoğun değil, birileri üzerinden de sesimizi duyurabiliyoruz.

- K.9: Sosyal medya üzerinden dahi ulaşabiliyoruz, ama sosyal medyayı daha etkin kullanırlar ise daha çabuk ulaşabiliriz. Sonuçta diğer şehirlerde Vali görmeyen insanlar var, bizim yönetim erkleri ile sürekli çarşı pazardan, restorana her yerde karşılaşabiliyoruz. Halktan kopuk değiller.

- K.10: Yerel yönetimimiz halk ile yakından alakall, sorunlar ile de ilgililer, bir etkinliğe davet etsek katılım gösterirler, yeniliklere açılar, demokratikler, çok memnunuz, sağ olsunlar.

\section{Yalova kenti dışında farklı bir kentte yaşama motivasyonuna yönelik veri- ler;}

- K.1: Sosyal ve kültürel yaşantısı ile doğasını seviyorum, bu sebeple olanaklar elverdiğince bu kentte yaşamak istiyorum. Ancak ülkemi seviyorum, işim gereği gelecek zamanlar ne gösterir ise realiteler çerçevesinde bir mecburiyet oluşur ise gerekeni yapmaktan başka bir çare olmayacaktr. Ancak bir tercih yapacak isem ve bu tercih hakkı benim ise tabi ki önceliklerimden biri bu şehirde yaşamak olacaktır. 
- K.2: Genç yaşımda bu kente çalışmak için gelmiştim, başka da bir yere gitmeyi düşünmedim.

- K.3: Bu kentte evlendim, yaşamımı kurdum, işim de bu kentte. Başka şehri hiç düşünmedim.

- K.4: Ailem ve sevdiklerim bu şehirde. Bu kente bağım çok fazla, gitmek istemem.

- K.5: Y1llar önce genç bir memur olarak geldim, sevdim, alıştım, yerleştim, gitmek istemem.

- K.6: Sülalem bu şehirde, işim burada, dedemle beraber Yalovalı olmuşuz, bırakıp gidemem.

- K.7: Genç yaşlarda daha büyük şehirlere gitmek istedim, gençken mümkün olmayınca 50 yaşımdayım, bu yaştan sonra başka bir şehre gidip yeni bir yaşam kurmaya cesaret edemem.

- K.8: Şehri sevmediğimden değil, eskiden İstanbul'a yerleşme fikrim vardı, istedim. Ailemi bırakamadım, sonra kabullendim, artık işimin başındayım, kısmetim ve ekmeğim bu şehirde.

- K.9: Yalova'nın yerlisiyim, 58 yaşındayım, ömrüm bu şehirde geçti, gençken başka hayallerim vardı ama yaş kemale erince bu şehir bana daha cazip gelmeye başladı.

- K.10: Babam gençken Yalova'ya yerleşmişti, bu şehirde büyüdüm, büyük şehirler gezmek için güzel ama iş yaşamaya gelince daha zor, karmaşık. Bizim şehrimiz yaşamak için ideal.

Yalova kentinin, kent kimliğine katkı sunması adına önerilere yönelik veriler;

- K.1: Yalova'nın daha iyi tanıtılması gerektiğine inanıyorum, ülkemizde hala Yalova'nın bir şehir olduğunu bilmeyenler vardır. Kimi bir ilçe olarak görüyor kimi de Bursa Yalova tamlamasını kullanıyor. Bu da şunu göstermektedir ki çoğu kimse Yalova'nın 1996 yılına kadar İstanbul'un bir ilçesi olduğunu ve 1996 yılından bu yana bir il olduğunu bilemiyor. Bu durum da Yalova kentinin iyi tanıtılmadığını göstermektedir.

- K.2: Bu denli merkezi konumda olan bir il ne yazık ki bir Sapanca kadar ya da bir Abant kadar tanınmıyor ki ilgili isimler ilçelerdir. Yalova ise bir kent, bu durumun sorgulanması gerektiğini düşünüyorum. 
- K.3: Yurt dişından birçok milliyetten bireyin tercih ettiği bir şehre, bu kadar doğa turizmi olanaklarına müsait olan Yalova'ya yerli turistin az ilgi göstermesini anlamlı bulmuyorum.

- K.4: Kentimizin reklamının kesinlikle daha fazla yapılması gerektiğine inanıyorum. Marka şehir olabilecek özellikte bir şehrimiz var, her imkan değerlendirilmelidir.

- K.5: Ulaşım açısından çok rahat bir şehir, büyükşehirlere yakın, böyle bir şehrin daha fazla imkanlarının olması gerektiğine inanıyorum. Hak ettiğimiz yerde olmadığımıza inanıyorum.

- K.6: Sanayi bakımından kentin gelişmesi gerekli, daha çok istihdam sağlanır ise şehrimiz daha çok kalkınır, pek çok doğal güzelliğimiz var, reklamımız az kalıyor, tanitım yapilmalı.

- K.7: Turizm cenneti olmalıyız, doğa sporları teşvik edilmeli, güzelliklerimiz ile ismimizden söz ettirmemiz gerekirken birçok şehirden geri kaldık, Yalova'yı hala ilçe sananlar var.

- K.8: Yerli turistten çok yabancı turistimiz var, ülke içi tanıtımımızın yapilması şarttır.

- K.9: Gençleri bu şehirde kalmaları için ikna etmeliyiz, kentin güzelliklerini gençlerimize ne kadar yaşatırsak şehri de o derece benimsetiriz, gençler şehrin geleceğini de şekillendirecektir.

- K.10: Yalova yaşayan bir şehir, tabiat güzelliği ve doğal imkanı çok, doğru değerlendirmek lazım, tanıtımı yapılmalı, istihdam ve sosyal imkanları artırılmalı, deprem adına çalışmalar yapılmalı, bir deprem olması durumunda çok hazırlıksız olduğumuzu düşünüyorum.

\section{Araştırmanın Bulgularına Dair Tartışmalar}

15 yıl ve üzeri süre ile Yalova kent merkezinde ikamet eden ve kentlilik bilinci hissiyatını kazandığı düşünülen, Lisans ve üzeri eğitim düzeyinde ölçeklenen, yaşları 25 ve 65 arasında değişkenlik gösteren, erkek ve kadın popülasyonunun, kentlilik bilinci düzeyini ve kentlilik deneyimlerini tespit etmeye yönelik olan çalışma kapsamında yürütülen görüşmeler sonucunda, verimli ve kayda değer bulgular edinilmiştir. Verilerin bulgularını şu şekilde okumak mümkündür; 
Yalova kentinde yaşama (bulunma) nedenine yönelik veriler; Katılımcların bir kısmınin memuriyet veya ticaret faaliyeti sebebi ile Yalova'ya tayinlerinin çıktığını, kısa sürede Yalova'yı yaşanabilir bir kent olarak algılayıp meslek yaşamlarının sonrasında kente yerleşme kararını aldıkları bulgulanmıştır. Bir kısmının ise Yalova kentinde dünyaya geldikleri veya kentlilerden biri ile evlilik gerçekleştirmeleri sebebi ile yerleştikleri görülmektedir.

Yalova kentine dair akılda kalan öğelere yönelik veriler; Yalova kentinin kaplıcaları (Termal ilçesi ve termal turizmi), Yürüyen Köşk'ü, plajları, temiz havası ve birbirinden güzel çiçekleri ile anıldığ ifade edilmek ile birlikte, kivi başta olmak üzere pek çok meyvesinin güzelliği, Çınarcık, Armutlu ve Esenköy ilçelerinin kamp ve ören yerleri ile şelaleleri ilk olmak üzere pek çok doğal güzelliği ile denizi ve dolayısı ile ulaşım kolaylığı ve dahi Atatürk'ün şehri olması hasebi ile akılda kalan Yalova, Erikli Yaylası ve Arboretumu ile de isminden söz ettirmektedir.

Yalova kentini tanıma ve farkındalık (tarihi, kültürel ve coğrafi özellikleri ile) düzeyine yönelik veriler; Araştırma dahilinde Yalova şehri, kentlileri tarafından tarihi, kültürel ve coğrafi yönleri ile yüksek düzeylerde bilinen ve tanınan bir şehir olarak bulgulanmaktadır. Kentte meydana gelen gelişmelerin takip edildiğini, doğal güzelliklerinin keşfedildiğini, tarihi ve kültürel özellikleri konusunda da farkındalık oluştuğunu ifade etmek mümkündür.

Yalova kentinin, kent olma özelliğini taşımasına yönelik veriler; Farklı kültürlerin, farklı etnik kökenlerin bir arada yaşadığı Yalova kentinde, farklı inançlara mensup, farklı dilleri konuşan ancak farklılıkları ile bir arada yaşama yetisine sahip bir popülasyon yaşamlarını idame ettirmektedirler. Yalova şehrinin İstanbul, Kocaeli ve Bursa gibi büyükşehirlere coğrafi bağlamda yakınlığı ve ulaşım imkanlarının kolaylığı, kentin ticaret, turizm alanında gelişimine katkı sağlar iken kültür, sanat ve sanayi alanlarında gelişmeye açık bir yapı sergilediği tespit edilen bulgular arasındadır. Tarihi ve kültür varlıkları ile ön plana çıkarılması gereken bir kent olması yönünde de katılımclar arasında bir görüş birliğinin varlı̆̆ını ifade etmek gereklidir.

Yalova kentinde yaşam ile mutluluk ilişkisine yönelik veriler; Katılımcılar tarafından Yalova'nın istihdam yetersizliği (işsizlik), sosyo-ekonomik imkanların darlığı (pahalılık) ve trafik başta olmak üzere, temel birkaç probleminin 
varlığı ortak görüş olarak bildirilmektedir. Mutluluk hissiyatının ekonomik, sosyal ve kültürel gelişmeler ile orantılı olduğunun farkındalığını yaşayan Yalova kentlileri, genel itibariyle Yalova kentinde yaşıyor olmaktan mutlu oldukların ifade etmektedirler.

Kendilerini Yalovalı olarak (kentsel aidiyet) tanımlama motivasyonuna yönelik veriler; Yalova kentinde varlık gösteren bireylerin kentin sakinliğinden, tabi güzelliğinden, diğer şehirlere dair ulaşım rahatlı̆̆ından, huzurlu atmosferinden, büyükşehirlerden farklı olarak mevcut yalın yaşam pratiklerinden, ihtiyaç duyabilecekleri birçok unsura kolaylıkla ulaşabildiklerinden, kentlilerin sıcak kanlılığının varlığından memnuniyet duydukları ve kente dair aidiyet hissedebilecekleri pek çok unsur elde edilen verilerin odağında toplanmaktadir.

Yalova kentinde mevcut gelişmelerin takip edilmesine (farkındahk) yönelik veriler; Katılımcıların genel itibariyle, yerel basın ve sosyal medya aracılığı ile kente dair sosyal ve kültürel gelişim sürecini takip ettikleri bulgulanan veriler arasında yer almaktadır. Yerel yönetimlerin kentlileri bilgilendirme konusunda başarılı oldukları da ayrıca tespit edilmiştir. Ve dahi, kentlilerin de Yalova şehrine dair gelişmeleri takip etmeye yönelik motivasyonları da dikkat çekici bir unsur olarak araştırma bulguları arasında kayıtlanmıştır.

\section{Yalova kent faaliyetlerine dair gönüllïlük motivasyonlarna (kent kurumla-} rına katılım) yönelik veriler; Şehrin kalkınması ve gelişmesi adına bu kente dair aidiyet hisseden bireylerin, kente katkı sunmaya gönüllü oldukları, sorumluluk almaya hazır oldukları, bazı katılımcıların çalışma saatlerinin uzun süreleri kapsaması sebebi ile arzu ettikleri düzeyde faaliyetlere katılamadıkları, kendileri olamasa da aile bireylerinin kent yönetimine katkı sağlamaya çalıştıkları, ancak vatandaş olarak ellerinden geldiği oranda katkı sunmaktan geri durmadıkları elde edilen verilerin odağında toplanmaktadır.

Yalova kentine dair geliştirilen sosyal ve duygusal bağlarn (kenti sahiplenme) varlığına yönelik veriler; Katılımcların imkanlarını daha yüksek düzeye eriştirmek istedikleri Yalova kentinde arkadaşlarının, tanışlarının ve akrabalarının varlığı başta olmak üzere ömürlerini bu kentte sürdürme motivasyonlarının yoğunluğu sebebi ile kente dair geliştirilen sosyal ve duygusal bağların yüksek düzeylere eriştiği tespit edilen bulgular arasındadır. Ayrıca, 
Yalova ile özdeşleşen hatıraların ve kent ile kesişen hayallerin varlığı, kentlilerin kenti sahiplenme bilinçlerini artırmakta ve kent ile duygusal bağ kurmalarını sağlamaktadır.

Yalova kentine dair mevcut olumsuzluklar karşılama biçimlerine (kente karşı sorumluluk) yönelik motivasyonları; Yalova kentinin küçük ve güzel bir şehir olmasına rağmen, kentin ulaşım arterlerine dair yaz aylarında oluşan yazlıkçı ve turist trafiğine bir çözüm üretilmesi, yakın zamanda yapılan İstanbul-İzmir otoyoluna Yalova merkezinden il çevre düzeni planında mevcut olan çevreyolunun başlatılması, kentin tanınabilirliğinin artırılması adına daha çok reklamının ve tanıtımının yapılması noktasında çalışmaların gerçekleştirilmesi, şehrin deprem riskinin düşünülerek, ciddi bir kentsel dönüşümün planlanması, pahalılık ve istihdam sorunlarına çözümler aranması, devlet dairelerinin birbirlerinden uzak noktalarda bulunmalarının zaman ve emek kaybına sebebiyet vermesi, trafik ve otopark sorunları adına çalışmaların ihtiyacının varlığı ve türevleri başta olmak üzere bazı sorunlarına kalıcı çözümler bulunamaması Yalova halkının kente dair güttükleri kaygılar olarak bulgulanmıştır.

Sosyal çevre bilinci edinme hissiyatına yönelik veriler; Bireylerin sosyal sorumluluk projeleri içerisinde yer almalarının önemi, şehrin kültürel yaşantısının daha da renklenmesi adına hem fiziki alanların artırılması hem de daha çok insanın katılabilmesi için kentin doğru tanıtılması gereksinimi, gençler adına mevcut imkanların çeşitlenmesi gerekliliği, kentin marka şehir olması adına faaliyetlerin yürütülmesi ihtiyacı, halka açık ve ücretsiz alanlar ile etkinliklerin çeşitlenmesi adına planların gerçekleştirilmesi, tabiat güzelliklerinin daha doğru değerlendirilmesi tespit edilen çevre bilinci edinme hissiyatına yönelik bulguları oluşturmaktadır. Ayrıca, Yalova kentinde farklı kültürden pek çok bireyin demokratik şartlarda yaşayabiliyor olmaları ve yerel yönetimlerin de sosyal çevre bilincinin oluşmasına yönelik faaliyetlerinin olduğunun kentliler tarafindan fark edilmesi tespit edilen önemli bulgular arasinda yerini almaktadır.

Kent aktivitelerine katılım hassasiyetine yönelik veriler; Katılımcıların mümkün mertebe kent aktivitelerine katılım sağlamaya çalıştıkları bulgulanan veriler arasında yer almaktadır. Kent aktivitelerinin tanıtımlarına hem 
yerel medyada hem de sosyal medyada ve dahi diğer reklam argümanlarında daha fazla yer verilmesi gerektiği genel kanaat olarak tespit edilmiştir. Eğitim ve halkın bilinçlenmesi adına konferansların düzenlenmesi, etkinliklerin uygun ücretler veya bila bedel ile halka sunulması, Üniversite tarafindan halka yönelik etkinliklere destek verilmesi talepleri de bulgulanan veriler arasında yerini almaktadır.

Bir sorun ile karşılaşıldığında yerel yönetimlere erişme (iletişim kurma) olanaklarna yönelik veriler; Yalova kenti yerel yönetiminin şehirlilere karşı ilgili oldukları, kentlilerin taleplerini dinledikleri ve çözüm arayışına girdikleri, kentlilerin kolaylıkla muhatap bulabildikleri, yönetim erklerinin kent halkının ve kurumlarının davetlerine icabet ettikleri, günlük yaşam pratikleri dahilinde yerel yönetim mensupları ile kentin hemen her noktasında karşılaşmalarının mümkün olduğu ve dahi sosyal medya kanalı ile de ulaşılabildikleri bulgulanan veriler arasındadır.

Yalova kenti dışında farklı bir kentte yaşama motivasyonuna yönelik veriler; Yaşam koşulları elverdiği sürece ve bir mecburiyet hali yaşanmaması durumunda katılımcıların yaşam tercihlerinin Yalova kentinden yana olduğu tespit edilen bulgular arasında yerini almaktadır. Genç popülasyonun özellikle istihdam ve daha gelişkin sosyo-ekonomik koşullar sebebi ile büyükşehirlere yerleşim planlarının olduğunu ancak, ağırlıklı olarak kentsel aidiyet duygusu ve sosyal çevrelerinden uzaklaşmak istememe sebepleri ile Yalova kenti yaşam alanları sıralamasında katılımcıların ilk tercihi olarak addedilmektedir.

\section{Yalova kent kimliğine dair katkı sunulması adına önerilere yönelik veriler;} Yalova kentinin daha etkin şekilde ve doğru yöntemler ile tanıtılması gerekliliği, Yalova kentinin bir ilçe imajından öteye taşınması ihtiyacı, nitel ve nicel manada daha fazla sayıda yerli turistin kente gelmelerinin teşvik edilmesi, marka şehir olma yolunda gerekli çalışmaların gerçekleştirilmesi, Yalova kentinin sahip olduğu güzelliklerin ve imkanların ön plana çıkarılması planlarının yürütülmesi, genç popülasyona başta istihdam ve sosyo-ekonomik koşullar olmak üzere çeşitli imkanların sağlanarak kentte kalmalarının teşvik edilmesi, sanayi sektörünün kente çekilmesi yönünde özendirilmesi, kentin bir turizm cenneti olması bağlamında kurguların tamamlanması ve deprem 
riski adına tedbirlerin alınması görüşleri, çalışmanın bulguları arasında yerini almaktadır.

\section{Sonuç}

Kent yaşamında konumlanmak ve kentlerin sunduğu imkanlardan faydalanmak isteyen ve kentlerde kendilerine birer yaşam kurmak isteyen bireyler, varlık gösterdikleri kenti bir yandan dönüştürürken öte yandan kendileri de çeşitli dönüşümlere uğramaktadırlar. Birey ve toplumların sahip oldukları kimliklerin birer yansıması haline dönüşen kentler, ekonomik, kültürel, sosyal, siyasal, tabi ve beşeri alanlarda kaydettikleri aşamalar ile birey ve toplumların hafızalarında yer edinerek birer kimlik kazanmaktadırlar. Kent kimliği, tarihsel süreç içerisinde, geçmişten günümüze her dönemin koşullarına göre şekillenen bir değişim içerisine girerek, farklı öğeler kazanmaktadır. Kente dair addedilen kimlik, yaşayan bir organizma olarak, kentin gerçek sahipleri olan kentlilerinin yaşam alanlarını yansıtan ve yaşam biçimlerinin izdüşümünü taşıyan bir olgudur. Bir kentin salt iklimi, topografyası, planlı mekan ve türevleri gibi örneklerini çoğaltmamızın mümkün olduğu fiziksel unsurların betimlemekle kalmayan kent kimliği, tabi, sosyal, ekonomik, kültürel, tarihi, coğrafi ve siyasi dokusunu da uhdesinde barındırarak, kentlilerin yaşam biçimlerini betimleyen bir kavram olarak addedilmektedir.

Günümüzün birey ve toplumlarınn en yoğun yerleşim birimlerinden olan kentler, bireyler adına istihdam alanları, yüksek yaşam standartlarına ulaşma konusundaki basamak, elverişli ve sağlıklı yaşam koşullarına eriştiren bir yol, hizmet alımı noktasında konforun temsili, refah seviyesini geliştirmek adına önemli bir araç, teknolojik gelişmelerin merkezi, ulaşım, iletişim ve altyapı hizmetleri bağlamında kaynak, ihtiyaçların karşılanması düşüncesinde zemin, sosyal boyutta odak ve kültürel anlamda bir düzlem merkezi olarak addedilmektedirler. Bu sebeple kentler, sürekli bir sirkülasyon (dolaşım) durumunun yaşandığı, göç yoğunluğunun söz konusu olduğu ve gelişmelere sürekli maruz kalan bir yapı olma özelliği ile birey ve toplumlar adına birer cazibe merkezleri olarak hafizalarda yer edinmektedirler. Ayrıca kentler, farklı yaşam biçimlerini ve özgün anlayış yapılarını uhdelerinde barındırma özelliği taşıyan demografik bir yer değişimi hareketinin çok ötesinde, toplumsal değişimlerin de beşiği olma niteliğini haiz yaşam alanlarıdır. Kentlerin gelişimlerinin devamlılığı, geleceklerinin korunması ve sürdürülebilir verimli faaliyetlerinin 
oluşturulması adına yönetim erklerinin çabaları, devlet politikaları ve yerel yönetimlerin faaliyetlerine koşut olarak, kent sınırlarında varlık gösteren kentlilerinin de kentlilik bilincine erişmeleri ile mümkün kılınmaktadır.

Zira, kentlilik bilinci kavramı, toplumsal yaşamın düzeni, kentsel yaşam kalitesi, farklılıkların bir arada yaşam kültürünü geliştirerek ortak yaşam pratiklerini oluş̧urmaları, kentin doğal ve kültürel zenginliklerinin korunması, kent kültürüne dair uygun görülen tutum ile davranış kurallarının geliştirilmesi, kent yaşamının sürdürülebilirliği adına kent suçlarının azalması ve türevleri başta olmak üzere, örneklerini çoğaltmanın mümkün olduğu ve ideal olarak nitelendirildiği bir anlayışın göstergesi olarak tanımlanmaktadır. Elbette kent bilincinin artırılması adına kentlerin kültürel, sosyal, ekonomik ile mekânsal gelişim ve dönüşümlerinin sağlanmasının önemi büyüktür. Uzun vadeli bir süreç olan kentlilik bilinci, kentte yaşayan bireylerin kenti benimsemeleri, kentte süregelen gelişmelere dair farkındalık oluşturmaları, kente dair sorumluluk hissiyatı taşımaları, kent ile özdeşleşerek kendilerini kentin bir parçası olarak algılamaları, kendilerini kente ait hissederek kenti sevmeleri, gelecek nesillerin yaşamlarını olumlu yönde etkilemek adına kentin geleceğinin inşasında rol üstlenmeleri, yaşanılabilir bir kent adına faaliyetler yürütmeleri ve kentin kimliği ile özdeşleşerek kente dair sorunların çözüm yollarını üretilmesinde özverili davranmalarıdır. Kentlilik bilinci salt devlet, yerel yönetimler ve sivil toplum kuruluşlarının idaresine bırakılmaktan öte kentlileşen bireyin de sorumluluk sahibi olduğu bir olgudur. Bütünleşik bakış açılarını gerektiren kentlilik bilinci, tüm paydaşların sorumluluk hissiyatı ile kente katkı sunmalarının arandığı bir farkındalık hareketidir.

Kentte yaşamın idame ettiren her bireyin görev ve sorumlulukların itina ile yerine getirdiği bir farkındalığa karşılık gelen kentlilik bilinci, sağlıklı, sürdürülebilir ve bilinçli bir kentin inşasında büyük önem arz etmektedir. Kentin tarihi geçmişi, kentte mevcut yaşam doyum oranı, kentin ihtiyaçlara yanıt verme düzeyi ile kentin gelişmiş yapısı bireylerin kentlilik bilincinin oluşmasında önemli bir etken olmakla birlikte, kentte mevcut yaşanmışlık olgusunun (doğum ile veya uzun süren ikamet) varlığı da kentlilik bilincinin psikolojik göstergelerini ifade etmektedir. Kentten belirli sebepler ile uzaklaşmış ve kente yeni gelen bireylere kentin kültürünün tanitılması ve yapısının bilgilendirilmesi, kentlilik bilincinin sürdürülebilirliği ve kent kimliğinin benimsetilmesi adına önem teşkil etmektedir. Yürütülen çalışma ile Yalova hal- 
kının kentlilik bilincinin yüksek düzeylere eriştiğini ifade etmek mümkündür. Bu anlayışla, Yalova kentlilerinin, farkındalık sahibi, kentini ve yaşadıkları mekanı özümseyen, kentin kimliği ile özdeşleşen, kent yaşamını benimseyen, kente dair aidiyet hissiyatı geliştiren, toplum yararına hizmet anlayışını benimseyen yerel yönetimlerin çalışmalarını takip ederek katılım ve katkı sağlayan, kentin geleceğinin kendilerinin, gelecek nesillerin ve ülkenin geleceği olduğunun ayırdına varan, sorumluluk dürtüleri gelişmiş, sahip oldukları hakların bilincinde ve birlikte yaşam pratiklerini deneyimleyerek, çokkültürlü yaşama saygilı bireyler olarak Yalova kentinde varlık gösterdiklerini ifade etmek mümkündür. 


\title{
EXTENDED ABSTRACT
}

\section{A Reading on Awareness of Urbanity Through City Identity Indicators: Yalova City Sample}

\author{
Sibel Akova \\ Yalova University
}

Urbanization and urbanization phenomena, as one of the socializing processes of the individual as a social being, make it possible to examine the concept of urban awareness, and are indicators of the sense of ownership criterion by the city citizens. Urban structures, which have been shaped with the transition to settled life, have been deemed to have changed in time with the requirements of each period and the conditions of each culture and have different meanings. Until this day, cities have survived by taking on different functions, different structures and different appearances, influenced by the conditions of the period, the environment and seasonal effects, natural events, political structures and cultural elements. Technological developments, fast industrialization, current advances in communication and transportation infrastructures, the effects of the globalization process, the increase in the rate of education and the widespread use of opportunities, migration from rural settlements to cities are regarded as processes that affect urban structures and the lives of urbanites. The preferableness, density, development and belonging of urban settlements where individuals live in ease of transportation, benefit from the possibilities of the city with their public and private spaces or natural form, meet their increasing expectations, and where environmental spaces are shaped according to needs and to increase the quality of life will also be realized at different levels. Not only cities have become living environment, but also they have become a phenomenon in which emotional bonds are developed, the instinct of protection and sense of belonging and responsibility emerge, and a consciousness is formed in which meanings are built.

The main problems of the research are the investigation of Yalova urban identity through the definitions made for urban identity, the Yalova citizens' sense of belonging towards the city of Yalova, their orientation towards urban awareness and the existence of the imagined identity of the Yalova province. 
With the identification of Yalova urban identity, determination of its qualities and elements constitutes the principal purpose of the study. To see the need of determining the urbanization, being urbanized and urban awareness of Yalova province constitutes the importance of the study.

The study was carried out as a descriptive research which is aimed at determining the current situation by conducting a field study. In order to establish a relationship in the context of facts and perceptions, it has been concluded that the study should be conducted with a qualitative research method. With the research, a general view of the urbanization, being urbanized and urban awareness of the Yalova province was made and the general view of the existing data on the sustainability of the city's development was tried to be found. In the study, phenomenology technique was used as the data collection technique. During the study process, Interviews were made for approximately 45 minutes with each participant. The study includes the 5-participant observation process in September, October and November 2019. The study group consists of 10 people which are 5 men and 5 females, whose biological ages are in the range between 25 and 65 . In the study, the daily life practices of the volunteer participants regarding the determination of the sense of urban awareness, their motivation for signifying the concepts of city and urbanity, their habits about urbanization and the period of urbanization based on the related reflex were examined.

The nature of the study, in which the problematic determination of the motivation and behavior patterns of individuals and societies to adapt to the city is tested, constitutes 10 female and male population whose ages are vary between 25 and 65, lives in the city center of Yalova for 15 years or more, scaled at the undergraduate and above education level, and who have adopted the urban awareness approach. The purpose is to participate on a voluntary basis of the participants residing in the city center of Yalova, that constitutes the research. In the study, in which detailed questions were asked on the measurement of the sense of belonging and urban awareness about the Yalova province, a research was carried out on the determination of the urban identity of Yalova. The purposive sampling method was used while creating a sample in the research process.

The ones who want to live the city life and get benefit from the opportunities provided by the cities and want to establish a life for themselves in the 
cities; transform the city in which they exist and also face with various transformations themselves. Cities, which have become a reflection of the identities of individuals and societies, gain an identity by taking a place in the memories of individuals and societies with the stages they have achieved in economic, cultural, social, political, natural and human fields. The identity of the city includes the physical elements of a city such as its climate, topography, designed places and its derivatives, and it also describes the life styles of the city dwellers by incorporating its natural, social, economic, cultural, historical, geographical and political texture. Cities are seen as the employment areas for people, a step to reach high living standards, a way to reach favorable and healthy living conditions, representation of comfort about taking service, an important implement to improve the level of welfare, center of technological developments, resources of transportation, communication and infrastructure services, a ground for meeting the needs, a focus in the social dimension and a center in the cultural sense. The continuity of the development of the cities is made possible by the efforts of the administrative authorities in order to protect their future and to create sustainable productive activities, in parallel with the state policies and the activities of the local administrations, the citizens living in the city borders reach the awareness of urbanity. It is possible to state that the awareness of the urbanity of the people who live in Yalova has reached high levels with the study. With this understanding, It is possible to express that Yalova citizens who know the city and the place they live in, realize that they are the future of generations and the country, who have developed responsibility drives, are aware of their rights and experience the practices of living together, respectful of multicultural life; and they identify with the identity of the city, adopt the urban life, develop a sense of belonging to the city, follow the work of local governments that adopt the service for community, participate and contribute to the future of the city.

\section{Kaynakça / References}

Castells, M. (1997). Kent, sımf, iktidar. Çev. A. Erendil, Ankara: Bilim ve Sanat Yayınları.

Creswell, J. W., (2013). Nitel araştırma yöntemleri: Beş yaklaşıma göre nitel araştırma deseni. Çev. Ed. M. Bütün ve S. B. Demir, Ankara: Siyasal Kitabevi.

Çolak, M, Türkmen, İ, ve Hanilçe, M. (2017). Halkın tarihi ve kültürel bilinç durumu: Tokat örneği. Sosyal Bilimler Araştırmalan Dergisi, 12(1), 81-102. 
Dey, I. (1993). Qualitative data analysis: A user-friendly guide for social scientists. London: Routledge Publications.

Shaukland, G. (1996). Tarihi değeri olan kentlere neden el atmalıyı. Çev. K. Tuncay, Kent ve Kültürü, içinde (s.24).

Harvey, D. (2006). Sosyal adalet ve şehir. Çev. M. Moralı, İstanbul:Metis Yayınları.

Kotler, P. (1993). Marketing places: Attracting Investment, industry and tourism to cities, states and nations. The Free Press, New York.

Lefebvre, H, (2007). Modern dünyada gündelik hayat. Çev. I. Gürbüz, İstanbul: Metis Yayınları.

Merriam, S. B., (2013). Nitel araştırma: Desen ve uygulama için bir rehber. Çev. Ed. S. Turan, Ankara: Nobel Yayınları.

Punch K. F., (2014). Sosyal araştırmalara giriş: Nicel ve nitel yaklaşımlar. Çev. Du. Bayrak, H. Bader Arslan ve Z. Akyüz, Ankara: Siyasal Kitabevi Yayınları.

Punch, K.F. (1998). Introduction to social research: Quantitative and qualitative approaches. London: Sage.

Simmel, G. (2011). Modern kültürde çatışma. Çev. T. Bora, N. Kalaycl, E. Gen, İstanbul: İletişim Yayınları.

Stevenson, D. (2003). Cities and urban cultures. McGraw-Hill International, England.

Strauss, A., ve Corbin, J. (1990). Basics of qualitative research: Grounded theory procedures and techniques. New Delhi: SAGE Publications.

T.C. Bayındırlık ve İskan Bakanlığı (2009). Kentlilik bilinci, kültür ve eğitim komisyonu raporu. Ankara: Kentleşme Şurasi.

Tannenbaum D., Schultz, D. (2005). Siyasi düşünce tarihi, filozoflar ve fikirleri. F. Demirci (Çev.), Ankara: Adres Yayınları.

Weber, M. (1996). The city. Trans. Ed. D. Martindale and G. Neuwirth, New York, The Free Press.

Weber, M., (2003). Şehir: Modern kentin oluşumu. Çev. M. Ceylan, İstanbul: Bakış Yayınları.

\section{Kaynakça Bilgisi / Citation Information}

Akova, S. (2020). Kent kimliği göstergeleri üzerinden kentlilik bilincine dair bir okuma: Yalova Kenti örneklemi. OPUS-Uluslararası Toplum Araştırmaları Dergisi, 16(Özel Sayı), 3344-3386. DOI: 10.26466/opus.770453 